\title{
25. ALTERATION IN SITE 501 (LEG 68) AND SITE 504 (LEG 69) BASALTS: PRELIMINARY RESULTS 1
}

\author{
Y. Noack, ${ }^{2}$ Laboratoire de Cristallographie, Minéralogie et Pétrographie, Université Louis Pasteur, \\ 67084 Strasbourg Cedex, France \\ and \\ R. Emmermann and H.-W. Hubberten, ${ }^{3}$ Institut fur Petrographie und Geochemie der Universitat Karlsruhe, \\ D-7500 Karlsruhe, Federal Republic of Germany
}

\begin{abstract}
The interaction of seawater with basalts in DSDP Hole 501 and the upper part of Hole 504B (Costa Rica Rift) produced oxidative alteration and a zonation of clay minerals along cracks. From rock edges to interiors in many cracks the following succession occurs, based on microscopic observations and microprobe analysis: iron hydroxides (red), "protoceladonite" (green), iddingsite (orange), and saponite (yellow). Clay minerals replace olivines and fill vesicles and cracks. Other secondary minerals are phillipsite, aragonite, and unidentified carbonates. Some glass is transformed to $\mathrm{Mg}$-rich palagonite. Bulk rock chemistry is related to the composition of the secondary minerals.

The zonation can be interpreted as a succession of postburial nonoxidative and oxidative diagenesis similar to that described in the Leg 34 basalts.
\end{abstract}

\section{INTRODUCTION}

Sites 501 and 504 are located 500 meters apart, near $1^{\circ} 13.6^{\prime} \mathrm{N}, 83^{\circ} 44.0^{\prime} \mathrm{W}$ in 5.9 m.y. old crust of the southern flank of the Costa Rica Rift, about $200 \mathrm{~km}$ south of the spreading center. At Site 501, a hole 73 meters deep was drilled into a basement with a heat flow of $204 \mathrm{~mW} \mathrm{~m}^{-2}$. The temperature at the sediment/basement interface was extrapolated to be $59^{\circ} \mathrm{C}$. At Site 504, two holes reached the basement, which was under 274 meters of pelagic sediments. In Hole 504A basalt was drilled for 12 meters. In Hole 504B, 214 meters of basalt were drilled during Leg 69, and the hole was further drilled during Leg 70 to a depth of 548 meters. Heat flow at Site 504 is about $196 \mathrm{~mW} \mathrm{~m}^{-2}$, and the temperature at the sediment/basement interface is $56^{\circ} \mathrm{C}$.

Massive flows, pillow units, and breccia zones were recovered from the three holes (Fig. 1). The rocks were either sparsely phyric or carried significant abundances of two phenocryst assemblages: (1) plagioclase, olivine, and chromian spinel or (2) plagioclase, clinopyroxene, and olivine, with phenocrysts listed in decreasing order of abundance (Natland et al., this volume).

Two types of alteration were encountered in the basalt cores recovered from Sites 501 and 504. In Holes 501 and 504A, as well as in the upper part of Hole 504B (down to Core 39), alteration probably took place at relatively low temperature in oxidizing conditions, as evidenced by the frequency of red zones in hand specimen and the presence of iron-oxyhydroxides. The other alter-

\footnotetext{
${ }^{1}$ Cann, J. R., Langseth, M. G., Honnorez, J., Von Herzen, R. P., White, S. M., et al., Init. Repts. DSDP, 69: Washington (U.S. Govt. Printing Office).

2 Present address: Laboratoire de Petrologie de la Surface, Université de Poitiers, 40, Avenue du Recteur Pineau, 86022 Poitiers Cedex, France.

${ }^{3}$ Present address: Inst. de Geología, Universidad Autónoma de Nuevo Leon, 67700 Linares, N. L., Mexico.
}

ation products, essentially various trioctahedral smectites, phillipsite, and aragonite, are also characteristic of the submarine weathering of oceanic basalts. The basalts from the lower portion of Hole 504B, on the other hand, exhibit rare green color zonation and contain abundant pyrite along with a mineral paragenesis that indicates hydrothermal alteration in suboxic to reducing conditions. This chapter deals with the preliminary results of our study of the oxidizing alteration of basalts from Sites 501 and 504 at relatively low temperature. Another chapter (Honnorez et al., this volume) discusses the effects of nonoxidizing to reducing hydrothermal alteration on the basalts from the lower portion of Hole 504B.

\section{METHODS}

Samples were selected for their alteration patterns in hand specimens from the glassy margins of pillow lavas and the vicinity of veins. Ninety-seven samples (Table 1) were studied by the methods following.

Fifty-eight samples were impregnated with epoxy before being thin sectioned (Crovisier, 1979) in order to preserve the secondary minerals (clays and zeolites).

Microprobe analyses were made on 29 thin sections using the CAMEBAX electron microprobe (Laboratoire de Chimie Minérale, Université de Nancy, Nancy, France). The analyses were made under the following conditions: operating voltage, $15 \mathrm{kV}$; probe current, 10 $\mathrm{nA}$; count time, $6 \mathrm{~s}$ for each of four groups of three elements $(\mathrm{Mn}-$ $\mathrm{Na}-\mathrm{K}, \mathrm{Fe}-\mathrm{Mg}-\mathrm{Ca}, \mathrm{Ni}-\mathrm{Al}-\mathrm{Ti}$, and $\mathrm{Zn}-\mathrm{Si}-\mathrm{Cr}$ ) and $24 \mathrm{~s}$ for the background; beam diameter, 1 to $3 \mu \mathrm{m}$, defocused to $5 \mu \mathrm{m}$ for zeolites.

The chemical analysis of 40 bulk rock samples was carried out at the Petrographisches Institut der Universität Karlsruhe, Karlsruhe, Federal Republic of Germany. A Phillips 240 X-ray fluorescence spectrometer was used to identify 10 major elements, gravimetric methods were used to identify 6 trace elements, and titration methods were used to identify $\mathrm{CO}_{2}$ and $\mathrm{H}_{2} \mathrm{O}$.

X-ray diffraction (XRD) obtained with a Siemens X-ray diffractometer (Laboratoire de Cristallographie, Minéralogie et Pétrographie, Université Louis Pasteur, Strasbourg, France) was used to analyze 36 samples of isolated minerals. Test conditions were as follows: 

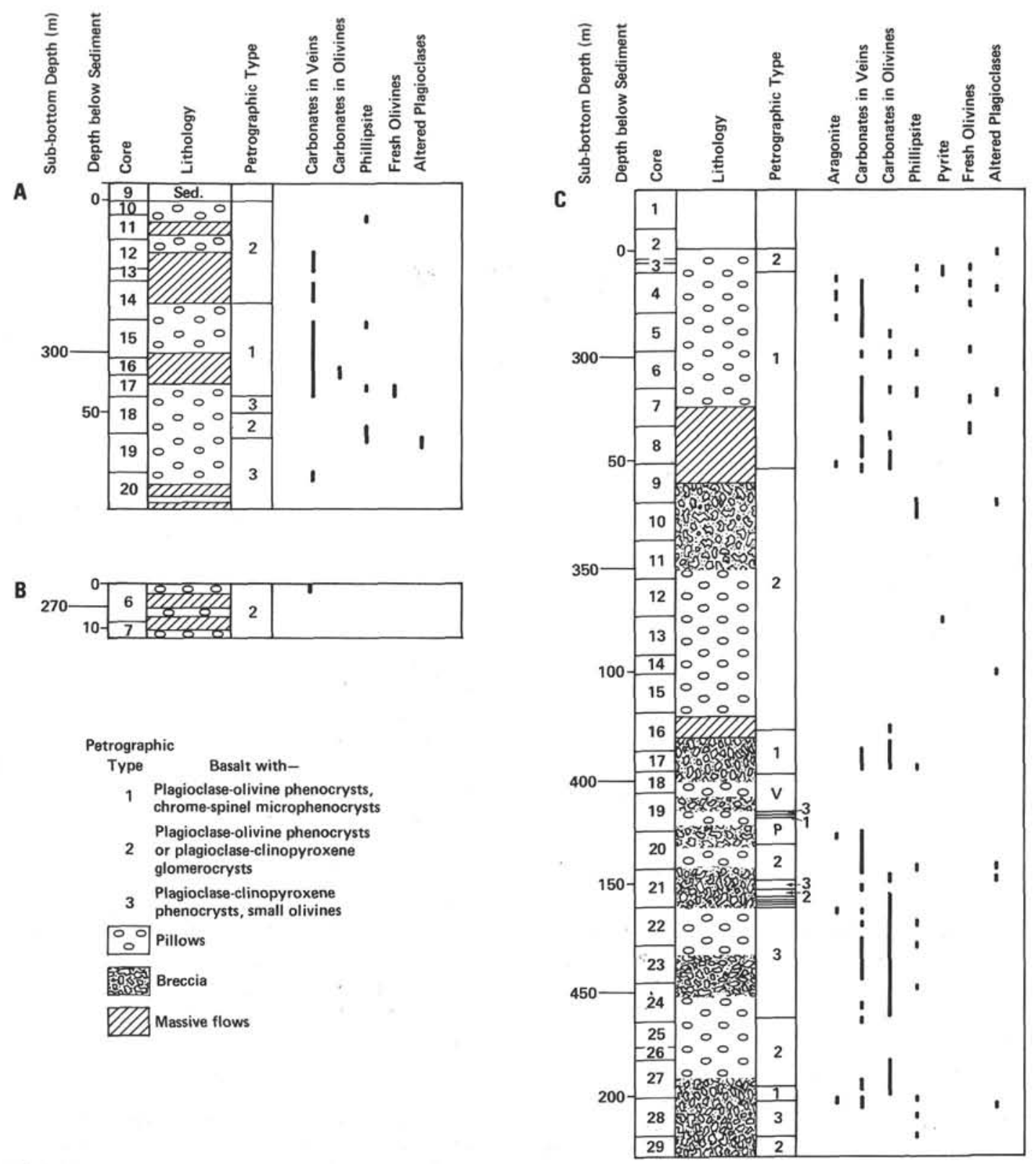

Figure 1. Schematic logs and distribution of secondary minerals other than clay minerals. (A) Hole 501. (B) Hole 504A.
(C) Hole 504B.

Ni-filtered monochromatic $\mathrm{Cu}-\mathrm{K} \alpha$ radiation, $30 \mathrm{kV} / 20 \mathrm{~mA}$; goniometer speed, $1 \% \mathrm{~min}$; paper speed, $1 \mathrm{~cm} / \mathrm{min}$.

\section{SECONDARY MINERAL IDENTIFICATION}

The secondary minerals found in the altered basalts from Holes 501 and 504A and the upper part of Hole 504B (which are limited in diversity compared with the secondary minerals in the lower part of Hole 504B [Honnorez et al., this volume]) fill vesicles and cracks and replace crystals of olivine and, more rarely, plagioclase. Pyroxene crystals are always unaltered. Plagioclase crystals are generally fresh except near large veins or in breccias. Fresh olivine relicts are found only in the upper 50 meters of Holes 501 and 504B. The distribu- tion of secondary minerals other than clay minerals is shown in Figure 1.

\section{Clay Minerals}

Clay minerals were observed in hand specimen and under the microscope, and, primarily on the basis of color in thin section, five types were distinguished (Table 2): dark green, yellow, gray, red, and green. The dark green and gray clays are found only in certain environments-dark green in large veins and breccia matrix and gray in olivine crystals. Clays of the other colors are almost equally distributed among the olivines, veins, and vesicles. 
The X-ray diffraction diagrams of the dark green, yellow, and gray clays are characteristic of trioctahedral smectites $(d(060)>1.529 \AA$ [Table 3]). The green clay shows a peak in $d(060)$ between 1.510 and $1.520 \AA$.

The clay minerals were analyzed by electron microprobe (Tables 4 and 5). Three sets of the clay minerals distinguished by microscopic observations also had different chemical compositions (Figs. 2 and 3). The yellow clays were rich in $\mathrm{MgO}(>15 \%)$, poor in $\mathrm{FeO}(<19 \%)$, and low in $\mathrm{K}_{2} \mathrm{O}$ content $(<1.5 \%)$. The red clays were poor in $\mathrm{MgO}(<20 \%)$, rich in $\mathrm{FeO}(>20 \%)$, and low in $\mathrm{K}_{2} \mathrm{O}$ content $(<1.5 \%)$. The green clays were very poor in $\mathrm{MgO}(<12 \%)$, rich in $\mathrm{FeO}(>20 \%)$, and high in $\mathrm{K}_{2} \mathrm{O}$ content $(>2 \%)$.

We were unable to analyze the dark green clay minerals; they were destroyed by the microprobe.

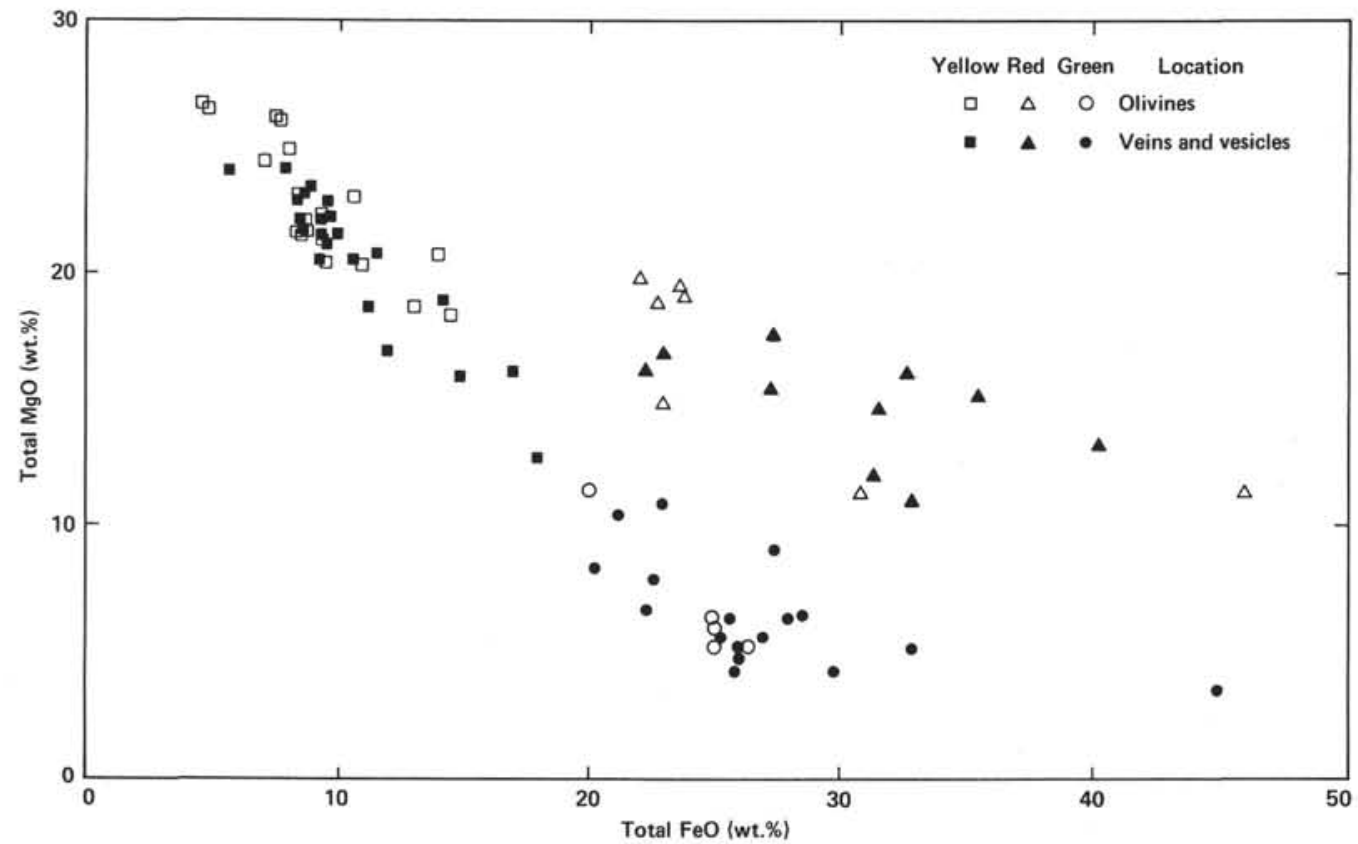

Figure 2. Content of $\mathrm{MgO}$ and $\mathrm{FeO}$ in clay minerals in Hole 504B.

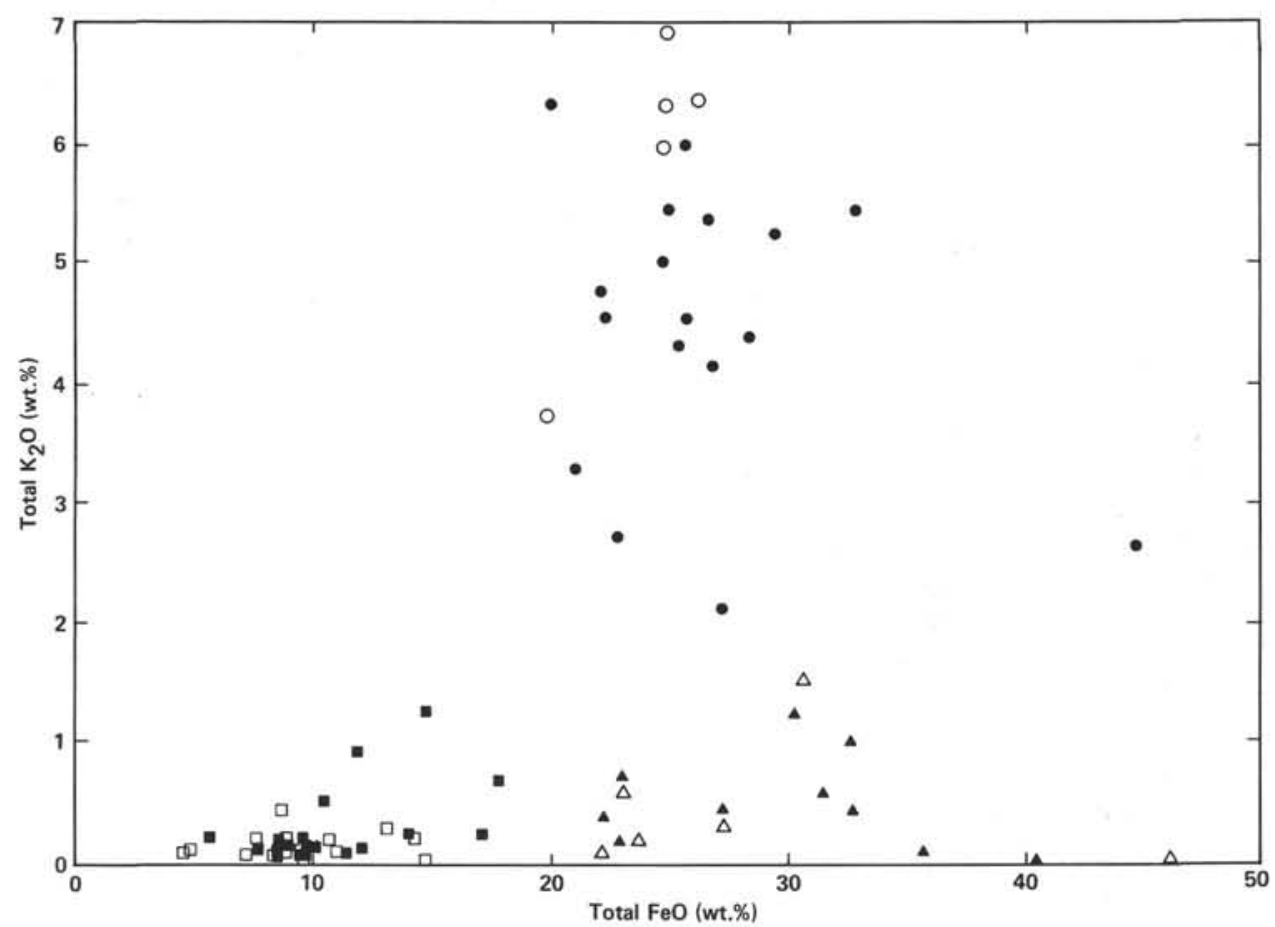

Figure 3. Content of $\mathrm{K}_{2} \mathrm{O}$ and $\mathrm{FeO}$ in clay minerals in Hole 504B. Symbols as in Figure 2. 


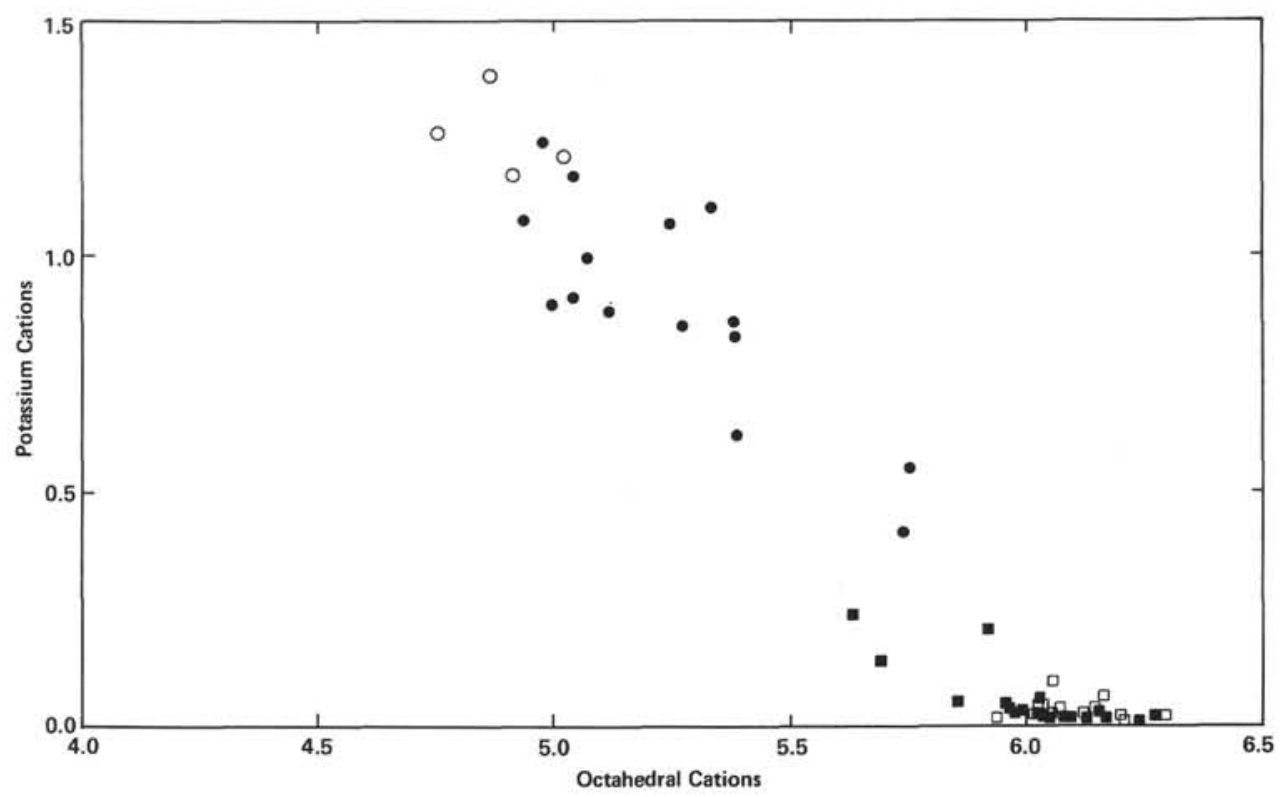

Figure 4. Potassium cation content and octahedral cation sum calculated for 22 oxygens for clay minerals in Hole 504B. Symbols as in Figure 2.

Cationic contents were calculated on the basis of 20 oxygens and 4 hydroxyls (a total of 44 cationic charges per formula unit). The octahedral cation sum ( $\mathrm{Al}^{\mathrm{vi}}+\mathrm{Fe}$ $+\mathrm{Mn}+\mathrm{Mg}$ ) is between 5.85 and 6.31 for the yellow clays (except in two samples) and between 4.75 and 5.76 for the green clays. The potassium cation content and the octahedral cation sum of both clays are inversely proportional and have a good linear correlation (Fig. 4). The yellow clay minerals appear to be saponites. By analogy with other DSDP samples (Andrews, 1980; Humphris, Thompson, et al., 1980; Mevel, 1980), the green clay minerals can be considered to be celadonite, the $\mathrm{K}$-Fe rich mica. However, the 10 - $\AA$ peak characteristic of mica was not detected by XRD. Therefore, in accordance with Donnelly et al. (1980), we shall called this green phyllosilicate protoceladonite. The octahedral cation sum of the red clay is greater than 6.5 , and so we assume that it is probably a mixture of saponite and iron hydroxides, that is, an iddingsite.

In addition to filling vesicles and cracks, the clay minerals replace olivine. This replacement entails changes from the primary phase chemical composition of the olivine. We estimated these changes for the transformation of olivine into saponite and protoceladonite by using known densities and assuming constant-volume transformations (Andrews, 1980). Olivine $\left(\mathrm{Ca}_{0.01} \mathrm{Mn}_{0.01} \mathrm{Fe}_{0.27}\right.$ $\mathrm{Mg}_{1.75} \mathrm{Si}_{0.98} \mathrm{O}_{4}$ ) from Sample 504B-4-7, 2-7 cm was chosen as the precursor. The most significant changes, besides the addition of $\mathrm{H}_{2} \mathrm{O}$, were as follows:

- Olivine $\rightarrow$ saponite-addition of $\mathrm{Al}, \mathrm{Ca}, \mathrm{Na}$, and $\mathrm{K}$; release of $\mathrm{Fe}, \mathrm{Mn}$, and $\mathrm{Mg}$; and small variations in $\mathrm{Si}$ and $\mathrm{Ti}$ in both directions.

- Olivine $\rightarrow$ protoceladonite-addition of $\mathrm{Ti}, \mathrm{Al}, \mathrm{Fe}$, $\mathrm{Ca}, \mathrm{Na}$, and $\mathrm{K}$; release of $\mathrm{Mn}$ and $\mathrm{Mg}$; and small variations of $\mathrm{Si}$ in both directions.

\section{Zeolites}

Contrary to the lower part of Hole 504B, the upper part of Hole 504B and Holes 501 and 504A contain only one zeolite-phillipsite. Phillipsite is a major constituent of both the veins in the glassy margins and (with dark green clay minerals) of the breccia matrix. Phillipsite is also associated with yellow clay minerals in a vein within a pillow core (Sample 504B-24-1, 64-67 cm).

Microprobe analysis shows an increase of the $\mathrm{Ca}$ content of phillipsite with increasing sample depth (Table 6). The $\mathrm{Si} / \mathrm{Al}$ ratio decreases but remains within the field of the deep sea phillipsites (Sheppard et al., 1970). Figures 5 and 6 indicate that in terms of chemical composition the Leg 69 phillipsites are intermediate between the Leg 46 and 49 phillipsites (Böhlke et al., 1980; Pritchard et al., 1979) and the Ca-rich Leg 51, 52, and 53 phillipsites (Donnelly et al., 1980).

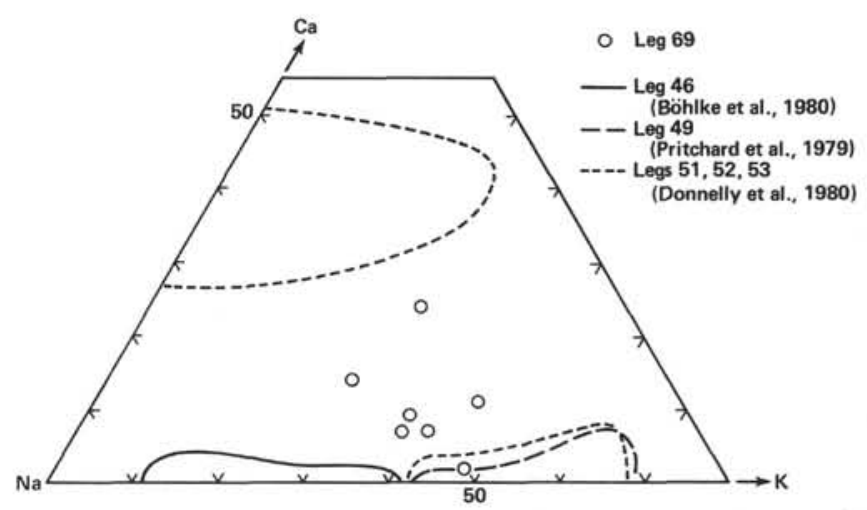

Figure 5. Ca-Na-K content of zeolites found in Holes 501 and 504B and on other legs. 


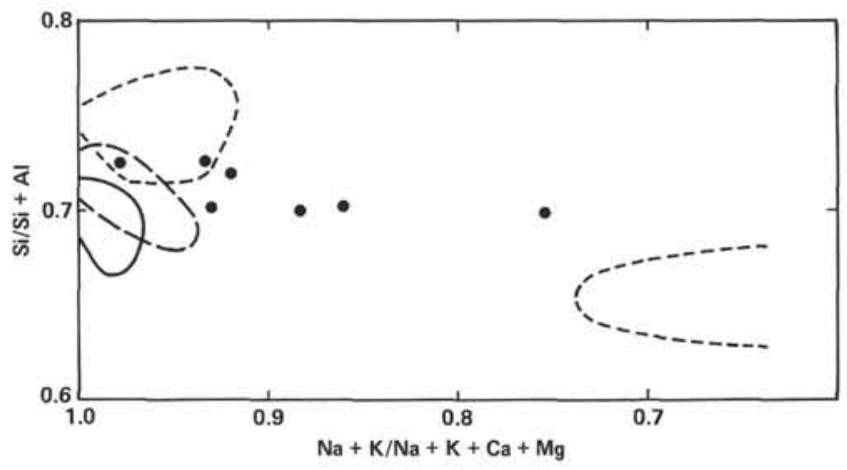

Figure 6. $\mathrm{Si} / \mathrm{Si}+\mathrm{Al}$ versus $\mathrm{Na}+\mathrm{K} / \mathrm{Na}+\mathrm{K}+\mathrm{Ca}+\mathrm{Mg}$ for zeolites found in Holes 501 and 504B and on other legs. Symbols as in Figure 5 .

\section{Carbonates}

Carbonates replace olivine and fill cracks. The carbonates that fill cracks are generally fibrous and were identified as aragonite by X-ray diffraction. Magnesian calcite $\left(9\right.$ mole $\left.\% \mathrm{MgCO}_{3}\right)$ was found associated with aragonite in Sample 504B-9-1, 38-42 cm. Aragonites from two veins were analyzed by microprobe (Table 7). The cell parameters of aragonite, which were calculated from X-ray diffraction data, vary slightly with depth: there is a slight decrease in the a and c parameters and a slight increase in the $b$ parameter. The calcium carbonate that replaces the olivine crystals has not yet been identified.

\section{Anhydrite}

An alteration product in an olivine phenocryst (Sample 504B-18-2, 101-105 cm) that was tentatively identified as anhydrite was analyzed by electron microprobe, but the identification was not confirmed by X-ray diffraction or by the analysis of the thin section under the microscope (Table 8). Its occurrence was confirmed by $\mathrm{XRD}$ and optics for several samples from the lower part of Hole 504B, however (Honnorez et al., this volume).

\section{ALTERATION OF GLASSY MARGINS}

Fresh glass is generally well preserved in the margins of the pillow lavas in the Leg 69 rocks. The width of the altered zone along cracks $(100 \mu \mathrm{m})$ is similar to that in the pillow lavas of Legs 37 and 45, which are approximately the same age. The altered glass (so-called palagonite) is not obvious in hand specimen. In thin section, palagonite appears yellow green, granular, and has very low birefringence. Two samples were analyzed by electron microprobe (Table 9 and Fig. 7). Palagonite has a lower content than fresh glass of $\mathrm{SiO}_{2}, \mathrm{TiO}_{2}, \mathrm{Al}_{2} \mathrm{O}_{3}$, $\mathrm{CaO}$, and $\mathrm{Na}_{2} \mathrm{O}$ but a higher content of $\mathrm{FeO}, \mathrm{MgO}$, and $\mathrm{K}_{2} \mathrm{O}$. The $\mathrm{K}_{2} \mathrm{O}$ content is lower and the $\mathrm{MgO}$ content is higher than in palagonites from Legs 37 or 45 to 46 (Noack, 1979). The differences in the chemical composition of the palagonites probably result from temperature differences during alteration. In the basalts recovered during Legs 37 and 45 to 46, the temperature of alteration was that of the bottom water. During Leg 69, the measured temperature was above $60^{\circ} \mathrm{C}$ (CRRUST, 1982). Seyfried and Bischoff (1979) have shown that near $70^{\circ} \mathrm{C}$ the direction of $\mathrm{Mg}$ and $\mathrm{K}$ migrations reverses.

\section{BULK ROCK ALTERATION}

In hand specimens, the basalts show color zonation along cracks. Two types of zonation, with the following color sequences, can be distinguished as one moves from the crack to the interior of the sample (Fig. 8): Type A (zones of dark gray, orange, and light gray); and Type B (zones of red, dark gray, and light gray).

In Type A alteration, the width of the dark gray zone and the orange zone each ranges from 0.5 to $2 \mathrm{~cm}$. The light gray zone is the innermost zone in both Type A and $\mathrm{B}$ alteration and borders fresh basalt. The boundaries between the different zones are very sharp, sometimes cutting across single olivine crystal or a vesicle. The color of each zone is the consequence of the replacement of olivine and the filling in of pores by secondary minerals. Examinations of thin sections show that zone color is related to the nature of the replacing clay minerals, as follows:

- The light gray zone is made up of yellow and gray clay minerals. The clays are lamellar in olivine but granular in vesicles. Fresh olivine relicts sometimes occur.

- The orange zone is made up of yellow and red clay minerals. Iddingsite follows saponite as one proceeds from the core to the rim of vesicles.

- The dark gray zone is made up of green clay minerals. In vesicles, protoceladonite follows saponite or iddingsite as one proceeds from core to rim.

- The red zone is made up of iron hydroxides.

\section{BULK ROCK CHEMISTRY AND RELATION TO SECONDARY MINERAL CHEMISTRY}

Thirty-six samples from Hole 504B were analyzed for bulk rock chemistry (Table 10). There appears to be little chemical variation due to magmatic processes with depth except in five analyses (Samples 504B-18-1 [110$115 \mathrm{~cm}$ ], 504B-19-1 [98-10 cm], 504B-19-1 [119-122 $\mathrm{cm}$ ], and 504B-21-2 [55-59 cm]) that show very different $\mathrm{TiO}_{2}$ values from the average and cannot be related to a primary or secondary petrographic character. Apart from these intervals the $\mathrm{TiO}_{2}$ values of fresh glass in the upper part of Hole 504B seem homogeneous (see Natland et al., this volume), and we can estimate the effects of alteration on bulk rock samples by comparing them to the glass compositions. For these reasons, the five analyses have not been considered in the following calculations.

Covariant relations were determined for the major elements (except $\mathrm{MnO}$ and $\mathrm{P}_{2} \mathrm{O}_{5}$ ), $\mathrm{Sr}$ content, and the oxidation coefficient $\left(\mathrm{Ox}=\left[\mathrm{Fe}_{2} \mathrm{O}_{3} / 80\right] /\left[\mathrm{Fe}_{2} \mathrm{O}_{3} / 80+\right.\right.$ $\mathrm{FeO} / 72$ ], Böhlke et al., 1980) (Table 11). Whereas the resulting rather good relations between $\mathrm{TiO}_{2}, \mathrm{Fe}_{2} \mathrm{O}_{3}$, $\mathrm{H}_{2} \mathrm{O}, \mathrm{Sr}$, and $\mathrm{Ox}$ are typical of altered basalts, the relations between $\mathrm{Na}_{2} \mathrm{O}$ and $\mathrm{H}_{2} \mathrm{O}$ and $\mathrm{Sr}$ are unexpected. To determine whether these unexpected relations were the result of passive accumulation, all the analyses were re- 

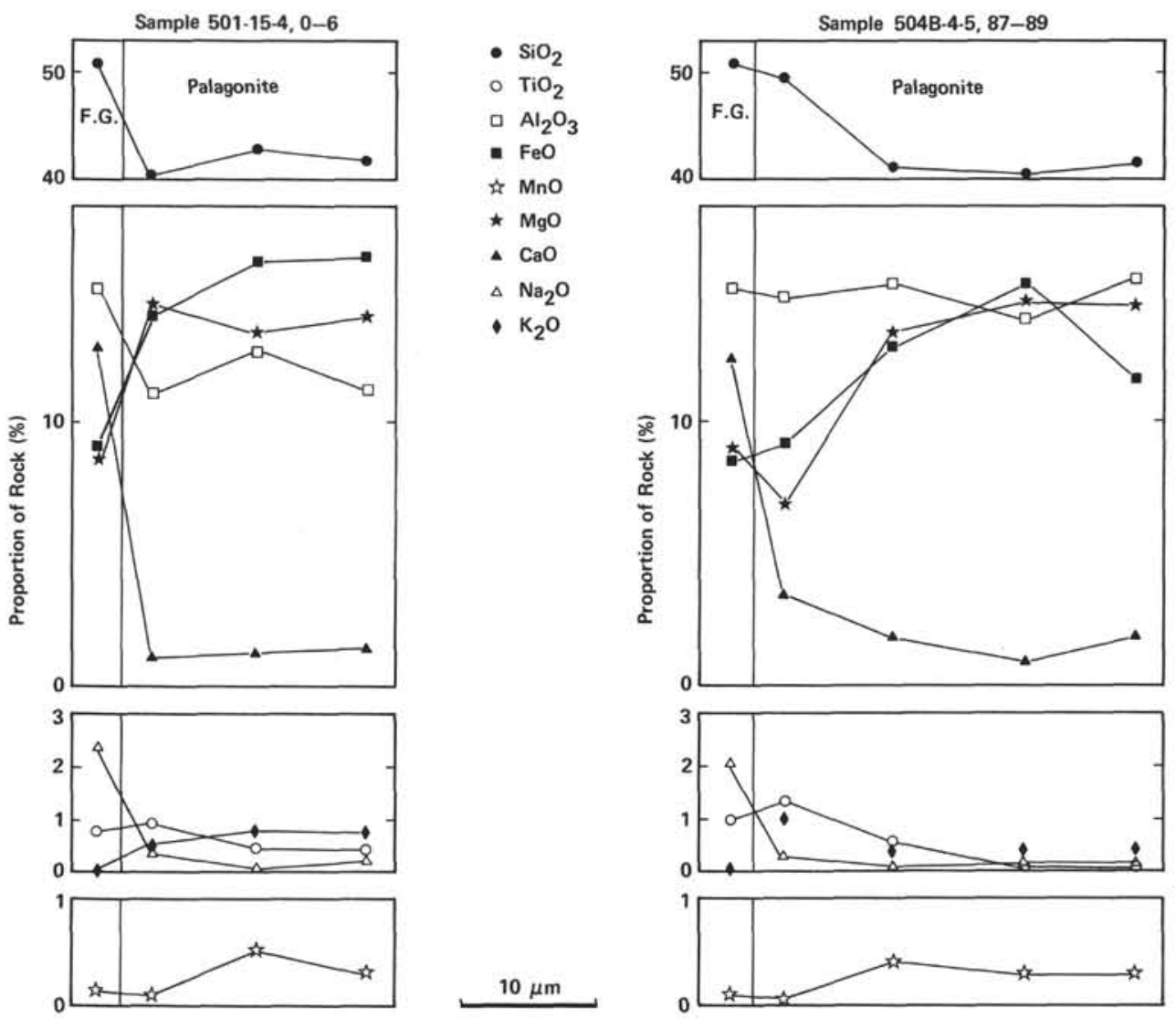

Figure 7. Oxide concentration in profiles across fresh glass and palagonite. F. G., fresh glass.

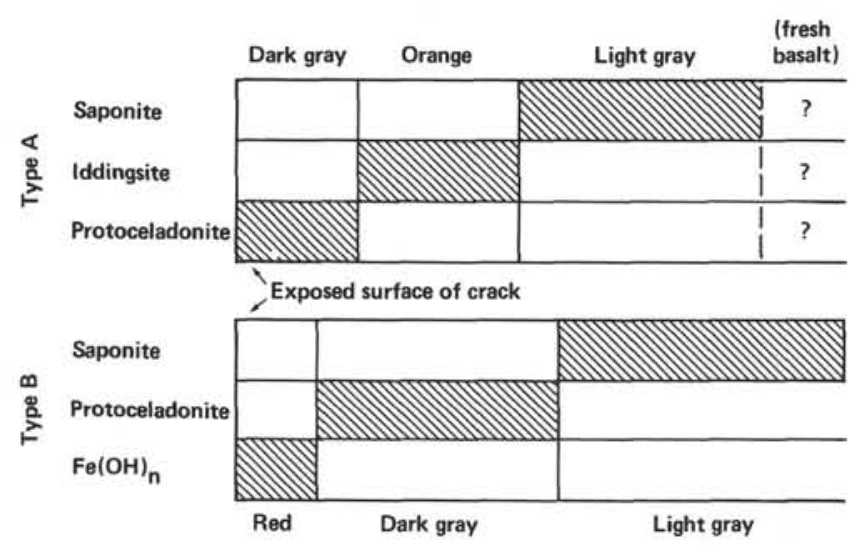

Figure 8. Color and composition of alteration minerals in altered zones.

calculated with a constant $\mathrm{TiO}_{2}$ value that represented the average of 15 fresh glass analyses from this part of the hole (Natland et al., this volume) and the analyses were compared to those of fresh glasses. $\mathrm{SiO}_{2}, \mathrm{Al}_{2} \mathrm{O}_{3}$, total iron, $\mathrm{MgO}$, and $\mathrm{CaO}$ show gains and losses in a range of $\pm 20 \%$. Some of these fluctuations result from different proportions of phenocrysts, chiefly plagioclase. $\mathrm{Na}_{2} \mathrm{O}$ gains are between 8 and $45 \%$. The $\mathrm{K}_{2}$ gains are very important (to $2800 \%$ ), but the $\mathrm{K}_{2} \mathrm{O}$ content of fresh glass is very low $(0.02 \%)$. The gains in $\mathrm{Na}_{2} \mathrm{O}$ and $\mathrm{K}_{2} \mathrm{O}$ are probably a consequence of the formation of protoceladonite and phillipsite, since they exceed that which might be caused by different proportions of phenocrysts.

Chemical differences between different color zones in a given sample are very small: $\mathrm{SiO}_{2}, \mathrm{Al}_{2} \mathrm{O}_{3}$, and $\mathrm{CaO}$ are nearly constant, there is little decrease in $\mathrm{MgO}$, and there are increases in total iron, $\mathrm{K}_{2} \mathrm{O}$, and the oxidation coefficient from the inner gray zone to the outer green zone. These observations are in agreement with the relationship between the $\mathrm{K}_{2} \mathrm{O}$ content and total iron/MgO ratio in bulk rock and in the secondary minerals of the same sample (Fig. 9). The increase in the total iron/MgO ratio in both the clay minerals and the bulk rock results from the replacement of saponite by iron-rich phases such as iddingsite and protoceladonite; the positive relation between the secondary minerals and bulk rock $\mathrm{K}_{2} \mathrm{O}$ contents can be related to the formation of protoceladonite.

More work is required to confirm our inferences based on this preliminary chemical correlation factor analysis.

\section{DISCUSSION OF RESULTS}

The alteration described in this chapter is similar to the alteration that has been found in the oceanic basalts recovered during other legs of the Glomar Challenger. This type of alteration, which been called submarine diagenesis, weathering, or low temperature alteration, usually takes place at temperatures ranging from bottom water temperature to a few degrees Celsius. At Sites 501 and 504 (excluding the lower part of Hole 504B), the 


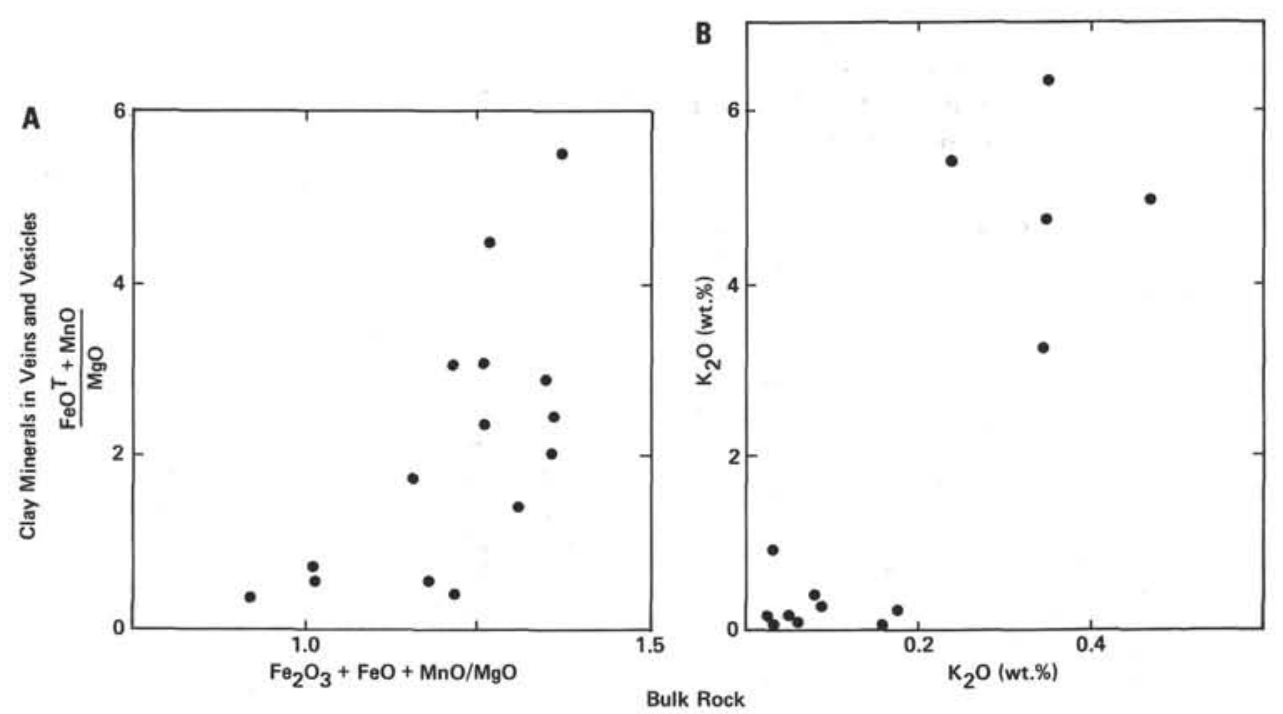

Figure 9. Relationship between chemistry of clay minerals and bulk rock in the same samples. Data are from Tables 5 and 10. (A) Iron content divided by magnesium content. (B) $\mathrm{K}_{2} \mathrm{O}$ content.

temperature appears to have been higher than $50^{\circ} \mathrm{C}$ during the basalt/seawater reactions, which is sure to have affected the chemistry of the alteration. For this reason it might seem appropriate to differentiate between low temperature alteration and the alteration that took place at Sites 501 and 504, even though the authigenic mineral parageneses that result from alteration at 0 and $50^{\circ} \mathrm{C}$ are very similar. However, it is difficult to base a definition of submarine weathering on temperature, because the alteration minerals characteristic of this alterationphillipsite, calcite, smectite, celadonite, and Fe-Mn hydroxides-crystallize under a very wide range of temperatures. Furthermore, we know that the authigenic mineral paragenesis observed in altered basalts from Sites 501 and 504 does not include any of the unequivocally metamorphic minerals, such as laumontite, wairakite, chlorite, or yugawaralite, which form at temperatures near or higher than $150^{\circ} \mathrm{C}$.

In the discussion following we will compare our preliminary mineralogical and geochemical data with the published results of similar studies made on altered basalts during DSDP Legs 34 and 37.

Bass (1976) explained the color zonation and related alteration mineral distribution in 40 m.y. old altered basalts from Leg 34 (Site 321) as the result of three low temperature alteration stages:

1) "preburial oxidative alteration," which is characterized by the replacement of glass by palagonite and the earthy $\mathrm{Fe}$-oxides after olivine in the pillow rims;

2) "postburial nonoxidative diagenesis," in which saponite replaces olivine and fills cracks (in association with $\mathrm{Mg}$-calcite and aragonite); and

3) "postburial oxidative diagenesis," which is characterized by the appearance of independent ferric phases. According to Bass, "the only phyllosilicate that seems to have formed under oxidative conditions is celadonite" (p. 430). He also says that "the advent of oxidative diagenetic conditions is marked by sharp, diffusioncontrolled fronts separating the gray, nonoxidatively altered rocks from red or brown, oxidatively altered ones" (p. 394).

Seyfried et al. (1978) described the transition between nonoxidative and oxidative diagenesis for the same hole. They noted that saponite, which had crystallized during nonoxidative alteration, was bleached of color and that ferrous iron, which had been leached from the basalt, was oxidized and formed iron-oxy-hydroxide floccules in veins and olivine pseudomorphs. They pointed out that "these floccules could then act as precursors for celadonite nucleation"' (p. 270) and that when adequate amounts of $\mathrm{Mg}^{2+}, \mathrm{K}^{+}$, and $\mathrm{SiO}_{2(\text { aq) }}$ were available, celadonite could precipitate. Further, they stated that "celadonite precipitation depleted the diagenetic fluid in $\mathrm{K}^{+}, \mathrm{Mg}^{2+}$ or $\mathrm{H}_{4} \mathrm{SiO}_{4}$ at a greater rate than that at which these components could be supplied from seawater and/or basalt, causing iron oxides to precipitate during later stages of infilling" (p. 270). They also noted that "silicate-hydrolysis and oxidation reactions produce a pH which is... slightly alkaline"' (p. 274) since, during saponite formation, an alkaline $\mathrm{pH}$ is present.

During Leg 37, oceanic crust ranging in age from 3.5 to $13 \mathrm{~m}$.y. was drilled at four locations (Sites 332 to 335 ) on a transect along the west flank of the Mid-Atlantic Ridge. Hole 332B, which is near the FAMOUS area, provided a section of $3.5 \mathrm{~m}$.y. old oceanic crust 582.5 meters long. Andrews (1980) considered the circulation of a small pulse of sea water through the rocks under oxidizing conditions, using the theory of infiltration metasomatism (Hoffman, 1972) to explain the sharp boundaries between the different zones. Andrews suggested that the seawater reacts with the first segment of fresh rock to form iron-oxides. Beyond this point, the water, somewhat reduced, reacts with basalt again, and celadonite crystallizes. Further reduced, the solution reacts with the inner parts of the rock to form saponite. Saponite continues to form until the fluid reaches an equilibrium with the basalt. A steady state process is established by the continued circulation of seawater, and 
the various zones advance simultaneously toward the rock interior. The following sequence of alteration minerals is generated, from the cracks inward and in the order of appearance: Fe-oxides (geothite or hematite), celadonite, saponite, and various carbonates. This process of oxidative alteration is the most widespread and important alteration process in the Leg 37 basalts. It occurred during and possibly immediately after the rapid cooling of the lavas by cold bottom water.

In summary, Bass (1976), Seyfried et al. (1978), and Andrews (1980), who observed a similar distribution of secondary minerals in altered pillow basalt in Site 321 and Hole 332B, disagreed on the sequence of the alteration stages.

In the Leg 69 cores no completely fresh basalts (basalts lacking any alteration minerals) were recognized. Samples drilled in young crust on both sides of the Galapagos Rift during Legs 54 and 70 (Humphris, Melson, et al., 1980; Honnorez et al., 1981) exhibit fillings of mixed $\mathrm{Fe}$-nontronite/celadonite with amorphous $\mathrm{Fe}$-oxides in dark halos around apparently fresh cores. Other samples showing this mineral sequence have been collected from the Mid-Atlantic Ridge rift valley in the FAMOUS area and dredged off the Vema Fracture Zone (Honnorez, unpublished data). Hence, one must be extremely careful when attempting to ascribe chemical parameters to given alteration stages on the basis of the presence of certain authigenic minerals in one's own rock samples or the samples of others. Assuming that the various alteration products have been properly identified, one should consider not only mineral assemblages (as opposed to single clay minerals) but also be open to the possibility of the recurrent precipitation of a given authigenic mineral during successive alteration stages.

In the case of the altered basalts from Leg 69 , Hole 504B, the two types of color zonation can be tentatively interpreted as resulting from two stages of a single low temperature alteration process. Type A (dark gray/orange/light gray) was followed by Type B (red/dark gray/ light gray). The order of these stages is the same as that for the last two stages described by Bass (1976) for Leg 34 , Site 321 but the reverse of the order suggested by Andrews (1980) for Leg 37, Hole 332B.

During the first stage, a relatively suboxic environment would have prevailed, and saponite would have replaced olivine phenocrysts and filled interstitial voids. As a consequence, yellow zones appeared along cracks and extended inward into fresh basalt rocks (Fig. 10A). Later, during a more oxidizing stage, small red spots of iron hydroxides appeared in saponite, which lost $\mathrm{Si}, \mathrm{Al}$, and $\mathrm{Mg}$ (Fig. 10B). When $\mathrm{Fe}, \mathrm{Si}, \mathrm{K}$, and $\mathrm{SiO}_{2(\mathrm{aq})}$ were sufficiently abundant in the interstitial fluid, celadonite precipitated (Fig. 10C). Finally, the final stage of Seyfried et al. (1978) was reached, and a zone of iron oxides formed (Fig. 10D).

\section{CONCLUSIONS}

Preliminary studies of the alteration products in Leg 68 , Site 501 and Leg 69 , Site 504 basalts show a succession of suboxic and oxidative conditions of alteration. During the suboxic stage, saponite was formed. During
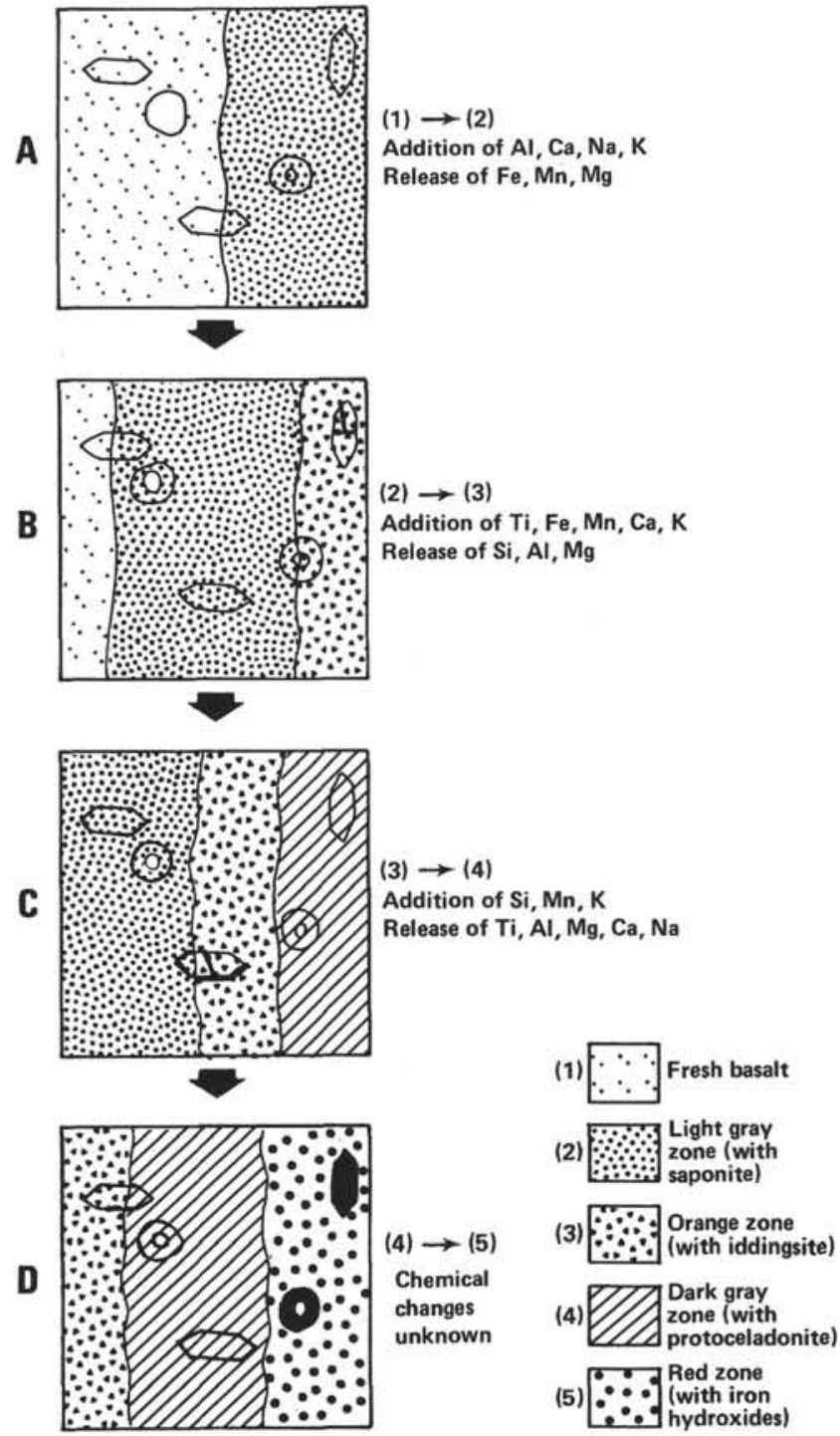

Figure 10. Schematic representation of the alteration of olivine. (A) to (D), successive alteration stages.

the oxidative phase, celadonite and iron hydroxide were formed. There are no visible variations with depth and temperature.

Complementary studies will allow us to better document the alteration process, including such environmental conditions as temperature and pore water composition and the evolution of the process through time.

\section{REFERENCES}

Andrews, A. J., 1980. Saponite and celadonite in Layer 2 basalts, DSDP Leg 37. Contrib. Mineral. Petrol., 73:323-340.

Bass, M. N., 1976. Secondary minerals in oceanic basalt, with special reference to Leg 34, Deep Sea Drilling Project. In Yeats, R. S., Hart, S. R., et al., Init. Repts. DSDP, 34: Washington (U.S. Govt. Printing Office), 393-432.

Böhlke, J. K., Honnorez, J., and Honnorez-Guerstein, B.-M., 1980 Alteration of basalts from Site 396B, DSDP: petrographic and mineralogic studies. Contrib. Mineral. Petrol., 73:341-364.

Crovisier, J. L., 1979. Techniques d'induration superficielle pour la réalisation de lames minces dans les matériaux poreux. Cah. ORSTOM, pedo., XVII:229-231. 
CRRUST, 1982. Geothermal regimes of the Costa Rica Rift, East Pacific, investigated by drilling, DSDP-IPOD Legs 68,69 and 70 . Geol. Soc. Am. Bull., 93:862-875.

Donnelly, T. W., Pritchard, R. A., Emmermann, R., and Puchelt, H., 1980. The aging of oceanic crust: synthesis of the mineralogical and chemical results of Deep Sea Drilling Project, Legs 51 through 53. In Donnelly, T., Francheteau, J., Bryan, W., Robinson, P., Flower, M., Salisbury, M., et al., Init. Repts. DSDP, 51, 52, 53, Pt. 2: Washington (U.S. Govt. Printing Office), 1563-1577.

Hofmann, A., 1972. Chromatographic theory of infiltration metasomatism and its application to feldspars. Am. J. Sci., 272:69-90.

Honnorez J., Von Herzen R. P., et al., 1981. Hydrothermal mounds and young ocean crust of the Galapagos: preliminary deep sea results, Leg 70. Geol. Soc. Am. Bull., 92:457-472.

Humphris, S. E., Melson, W. G., and Thompson, R. N., 1980. Basalt weathering on the East Pacific Rise and the Galapagos spreading center, Deep Sea Drilling Project Leg 54. In Rosendahl, B. R., Hekinian, R., et al., Init. Repts. DSDP, 54: Washington (U.S. Govt. Printing Office), 773-787.

Humphris, S. E., Thompson, R. N., and Marriner, G. F., 1980. The mineralogy and geochemistry of basalt weathering, Holes 417 A and 418A. In Donnelly, T., Francheteau, J., Bryan, W., Robinson, P., Flower, M., Salisbury, M., et al., Init. Repts. DSDP,
51, 52, 53, Pt. 2: Washington (U.S. Govt. Printing Office), 1201-1217.

Mevel, C., 1980. Mineralogy and chemistry of secondary phases in low temperature altered basalts from Deep Sea Drilling Project Legs 51, 52, and 53. In Donnelly, T., Francheteau, J., Bryan, W., Robinson, P., Flower, M., Salisbury, M., et al., Init. Repts. $D S D P, 51,52,53$, Pt. 2, Washington (U.S. Govt. Printing Office), 1299-1318.

Noack, Y., 1979. Alteration sous-marine des verres volcaniques basiques: essai sur la palagonitisation [Thesis]. University of Strasbourg, France.

Pritchard, R. G., Cann, J. R., and Wood, D. A., 1979. Low temperature alteration of oceanic basalts, D.S.D.P. Leg 49. In Luyendyk, B. P., Cann, J. R., et al., Init. Repts. DSDP, 49: Washington (U.S. Govt. Printing Office), 709-714.

Seyfried, W. E., Jr., and Bischoff, J. L., 1979. Low temperature basalt alteration by seawater: an experimental study at $70^{\circ} \mathrm{C}$ and $150^{\circ} \mathrm{C}$. Geochim. Cosmochim. Acta, 43:1937-1947.

Seyfried, W. E., Jr., Shanks, W. C., III, and Dibble, W. E., Jr., 1978. Clay mineral formation in DSDP Leg 34 basalt. Earth Planet. Sci. Lett., 41:265-276.

Sheppard, R. A., Gude, A. J., III, and Griffin, J. J., 1970. Chemical composition and physical properties of phillipsite from the Pacific and Indian Oceans. Am. Min., 55:2053-2062.

Table 1. Samples and analytical methods used.

\begin{tabular}{|c|c|c|c|c|c|c|c|}
\hline $\begin{array}{c}\text { Sample } \\
\text { Interval } \\
(\mathrm{cm})\end{array}$ & Piece & $\begin{array}{l}\text { ub-bottom } \\
\text { Depth } \\
\text { (m) }\end{array}$ & $\begin{array}{l}\text { Sample } \\
\text { Code }^{\mathrm{a}}\end{array}$ & $\begin{array}{l}\text { Thin } \\
\text { Section }\end{array}$ & $\begin{array}{l}\text { Microprobe } \\
\text { Analysis }\end{array}$ & $\begin{array}{l}\text { Bulk Rock } \\
\text { Analysis }\end{array}$ & $\mathrm{XRD}$ \\
\hline $501-11-1(0-3)$ & 37 & 267.3 & No & - & - & & \\
\hline $14-3(133-135)$ & 188 & 287.4 & No & 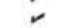 & & & \\
\hline $15-1(114-117)$ & 212 & 293.3 & No & 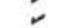 & & & \\
\hline $15-4(0-6)$ & 250 & 296.6 & No & 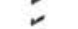 & - & & \\
\hline $16-2(26-29)$ & 280 & 302.9 & No & 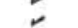 & & & \\
\hline $18-2(30-36)$ & 354 & 311.9 & No & 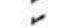 & & & \\
\hline $19-1(0-3)$ & 367 & 319.1 & No & 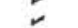 & & & \\
\hline $19-1(73-77)$ & 372 & 319.8 & TS & 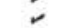 & - & & \\
\hline $19-1(113-117)$ & 376 & 320.2 & No & - & & & \\
\hline $504 A-6-1(50-52)$ & 11 & 265.5 & PE & & & - & \\
\hline 6-1 (134-138) & 25 & 266.4 & PE & & & $z$ & \\
\hline $6.2(88-96)$ & 40 & 267.4 & $\mathrm{PE}$ & & & - & \\
\hline $6-3(39-42)$ & 52 & 268.4 & No & r & & & \\
\hline $6-3(58-60)$ & 54 & 268.6 & No & 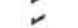 & & & \\
\hline $7.1(50-53)$ & 65 & 273.5 & No & $\sigma$ & & & \\
\hline $7.2(48-52)$ & 81 & 275.0 & PE & & & - & \\
\hline $7.2(105-110)$ & 84 & 275.6 & NO & r & & 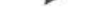 & \\
\hline $504 \mathrm{~B}-2-1(50-55)$ & 232 & 270.5 & No & r & & & - \\
\hline $3-1(16-19)$ & 241 & 278.2 & $\mathrm{PE}$ & & & r & \\
\hline $4-1(0-5)$ & 264 & 280.0 & No & & & & r \\
\hline $4-1(35-40)$ & 269 & 280.4 & $\mathrm{PE}$ & & & r & \\
\hline 4-1 (94-98) & 279 & 281.0 & NO & & & & r \\
\hline 4-1 (104-109) & 281 & 281.1 & No & & & & 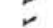 \\
\hline $4-2(0-15)$ & 291 & 281.6 & No & & & & 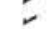 \\
\hline $4.2(122-128)$ & 308 & 282.7 & No & & & & 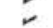 \\
\hline $4-3(91-94)$ & 320 & 283.9 & No & & & & \\
\hline $4-4(2-7)$ & 327 & 284.5 & No & r & 一 & & r \\
\hline $4-4(32-35)$ & 329 & 284.8 & No & 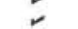 & 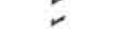 & & 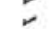 \\
\hline $4-4(140-145)$ & 343 & 285.9 & NO & & & & 2 \\
\hline $4-5(65-70)$ & 351 & 286.7 & No & & & & 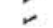 \\
\hline $4-5(87-89)$ & 353 & 286.9 & TS & r & r & & \\
\hline $4-5(102-108)$ & 355 & 287.0 & No & 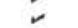 & & & \\
\hline $5-1(63-65)$ & 362 & 290.1 & No & 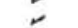 & & & \\
\hline $5-1(106-109)$ & 370 & 290.6 & PE & & & - & \\
\hline $5.1(142-147)$ & 372 & 290.9 & No & r & r & & r \\
\hline $5-2(15-20)$ & 374 & 291.2 & No & & & r & \\
\hline $5-3(2-6)$ & 388 & 292.5 & No & & & & r \\
\hline $6-2(2-3)$ & 414 & 300.0 & No & & & & 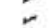 \\
\hline $6.2(90-95)$ & 422 & 300.9 & No & 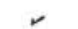 & r & & 5 \\
\hline $6-2(108-112)$ & 423 & 301.1 & PE & & & r & \\
\hline $7-1(93-97)$ & 444 & 308.4 & No & $\sigma$ & r & & \\
\hline $7-2(14-20)$ & 454 & 309.2 & NO & 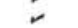 & 2 & & - \\
\hline $7-5(63-65)$ & 515 & 314.1 & PE & & & r & \\
\hline $8-1(1-2)$ & 519 & 316.5 & $P E$ & & & 2 & \\
\hline $8-2(45-52)$ & 528 & 318.5 & No & r & r & 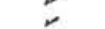 & \\
\hline $8-2(134-135$ & 534 & 319.3 & TS & - & - & & \\
\hline $8.4(120-123)$ & 557 & 322.2 & PE & & & r & \\
\hline $9-1(38-42)$ & 571 & 325.9 & NO & r & - & 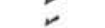 & $r$ \\
\hline $9-1(120-123)$ & 581 & 326.7 & TS & 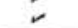 & - & & \\
\hline
\end{tabular}

\begin{tabular}{|c|c|c|c|c|c|c|c|}
\hline $\begin{array}{c}\text { Sample } \\
\text { Interval } \\
(\mathrm{cm})\end{array}$ & Piece & $\begin{array}{l}\text { ubb-bottom } \\
\text { Depth } \\
\text { (m) }\end{array}$ & $\begin{array}{l}\text { Sample } \\
\text { Code }^{2}\end{array}$ & $\begin{array}{l}\text { Thin } \\
\text { Section }\end{array}$ & $\begin{array}{c}\text { Microprobe } \\
\text { Analysis }\end{array}$ & $\begin{array}{c}\text { Bulk Rock } \\
\text { Analysis }\end{array}$ & XRD \\
\hline $9-2(80-83)$ & 597 & 327.8 & PE & & & r & \\
\hline $10-1(13-17)$ & 608 & 334.6 & No & - & & & r \\
\hline $10-2(12-14)$ & 628 & 336.1 & $\mathrm{PE}$ & & & r & \\
\hline $10-3(80-85)$ & 653 & 338.3 & No & r & & & r \\
\hline $10-3(88-92)$ & 655 & 338.4 & TS & r & - & & \\
\hline $13-3(79-83)$ & 793 & 365.3 & NO & 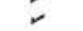 & & & r \\
\hline $13-4(6-10)$ & 802 & 366.1 & No & - & r & & \\
\hline $15-1(10-15)$ & 870 & 375.1 & No & - & & & $r$ \\
\hline $15-5(95-100)$ & 935 & 382.0 & NO & $\sim$ & & & - \\
\hline $16-2(5-10)$ & 975 & 385.6 & No & & & r & \\
\hline $16-4(62-67)$ & 1009 & 389.1 & No & r & & & \\
\hline $17-1(145-150)$ & 1049 & 394.5 & NO & 2 & r & & r \\
\hline $17-2(86-90)$ & 1064 & 395.4 & No & 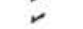 & & r & \\
\hline $17-2(130-137)$ & 1069 & 395.8 & PE & & & r & \\
\hline $18-1(110-115)$ & 1095 & 399.1 & PE & & & - & \\
\hline $18-2$ (101-105) & 1112 & 400.5 & NO & r & - & & \\
\hline $19-1(98-103)$ & 1126 & 404.0 & PE & & & r & \\
\hline $19-1(119-122)$ & 1129 & 404.2 & No & r & r & r & \\
\hline $19-2(23-25)$ & 1135 & 404.7 & NO & 2 & & & - \\
\hline $19-2$ (93-95) & 1146 & 405.4 & PE & & & r & \\
\hline $20-1(58-61)$ & 1166 & 412.6 & NO & - & r & - & \\
\hline $21-1$ (11-15) & 1180 & 421.1 & No & 2 & - & & - \\
\hline $21-1(70-75)$ & 1188 & 421.7 & TS & - & - & & \\
\hline $21-1(132-135)$ & 1192 & 422.3 & No & $r$ & r & r & \\
\hline $21-2(55-59)$ & 1208 & 423.0 & No & 2 & - & r & \\
\hline $21-3(145-150)$ & 1236 & 425.5 & NO & & & r & \\
\hline $21-4(45-49)$ & 1244 & 426.0 & NO & r & & & \\
\hline $22-1(18-20)$ & 1270 & 430.2 & No & 2 & & & r \\
\hline $22-2(124-127)$ & 1298 & 432.8 & No & & & & - \\
\hline $23-1(2-6)$ & 1310 & 439.0 & No & & & & - \\
\hline $23-1$ (73-75) & 1320 & 439.7 & PE & & & $r$ & \\
\hline $24-1(64-67)$ & 1339 & 448.7 & NO & r & & & \\
\hline $24-1(101-105)$ & 1347 & 449.0 & No & & & & r \\
\hline $24-2(69-73)$ & 1362 & 450.2 & NO & r & - & & \\
\hline $24-3(29-32)$ & 1379 & 451.3 & No & 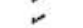 & & & r \\
\hline $25-1(34-38)$ & 1402 & 457.4 & NO & 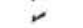 & r & - & \\
\hline $25-2(36-38)$ & 1425 & 458.9 & PE & & & r & \\
\hline $27-1(105-110)$ & 1473 & 467.1 & PE & & & r & \\
\hline $27-1(140-145)$ & 1477 & 467.4 & No & r & & & $r$ \\
\hline $27.2(10-14)$ & 1479 & 467.6 & NO & 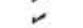 & & & $r$ \\
\hline $28-1(48-51)$ & 1492 & 475.5 & No & r & & & r \\
\hline $28-2(8-10)$ & 1503 & 476.6 & No & & & & r \\
\hline $28-2(90-95)$ & 1513 & 477.4 & No & ـ & & & $r$ \\
\hline $28-3(120-125)$ & 1536 & 479.2 & NO & - & r & & 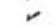 \\
\hline $28-4(125-130)$ & 1553 & 480.8 & $\mathrm{PE}$ & & & - & \\
\hline $28-5$ (14-17) & 1558 & 481.7 & No & - & r & $r$ & \\
\hline $29-1$ (11-14) & 1560 & 484.1 & No & r & r & & r \\
\hline $29-1(50-52)$ & 1569 & 484.5 & PE & & & $r$ & \\
\hline
\end{tabular}

${ }^{a}$ NO, Noack; PE, Puchelt-Emmermann; TS, shipboard sample. 
Table 2. Characteristics of the clay minerals observed at Sites 501 and 504.

\begin{tabular}{|c|c|c|c|c|c|}
\hline \multirow[b]{2}{*}{ Type } & \multirow{2}{*}{$\begin{array}{l}\text { Macroscopic } \\
\text { Color }\end{array}$} & \multirow{2}{*}{$\begin{array}{l}\text { Microscopic } \\
\text { Texture }\end{array}$} & \multicolumn{2}{|c|}{ Color } & \multirow[b]{2}{*}{ Distribution } \\
\hline & & & Plane Light & Crossed Nicols & \\
\hline Dark green & Dark green & Fibrous & Yellow green & Yellow gray & $\begin{array}{l}\text { Breccia matrix, } \\
\text { large cracks }\end{array}$ \\
\hline Yellow & Gray green & $\begin{array}{l}\text { Fibrous, lamellar, } \\
\text { granular }\end{array}$ & Yellow brown & $\begin{array}{l}\text { Second } \\
\text { order }\end{array}$ & $\begin{array}{l}\text { Olivine, vesicles, } \\
\text { veins }\end{array}$ \\
\hline Gray & Gray green & Lamellar & Pale green, coloriess & Gray & Olivine \\
\hline Red & Red orange & & Red brown & Red brown & $\begin{array}{l}\text { Olivine, vesicles. } \\
\text { veins }\end{array}$ \\
\hline Green & Green & Granular & Light green & Dark green & $\begin{array}{l}\text { Olivine, vesicles. } \\
\text { veins }\end{array}$ \\
\hline
\end{tabular}

Table 3. X-ray diffraction data for clay minerals in olivines, veins and vesicles, and breccia matrix.

\begin{tabular}{|c|c|c|c|c|}
\hline & $d(001)$ & $d(110)$ & $d(200)$ & $d(060)$ \\
\hline \multicolumn{5}{|l|}{ Olivine } \\
\hline $\begin{array}{r}\text { Sample 504B-4-4 (32-35) } \\
6-2(2-3)\end{array}$ & & $\begin{array}{l}4.64 \\
4.62\end{array}$ & 2.53 & 1.540 \\
\hline $6-2(90-95)$ & 14.2 & 4.63 & 2.54 & 1.529 \\
\hline $13-3(79-83)$ & & 4.59 & & 1.531 \\
\hline $15-5(95-100)$ & 12.6 & 4.59 & & 1.530 \\
\hline $17-1(145-150)$ & 14.5 & 4.61 & 2.56 & 1.532 \\
\hline $22-1(18-20)$ & 14.4 & 4.64 & 2.57 & 1.534 \\
\hline $22-2(124-127)$ & 15.4 & 4.64 & 2.55 & 1.538 \\
\hline $24-1(101-105)$ & 13.0 & 4.59 & & 1.530 \\
\hline $24-3(29-32)$ & 15.2 & 4.59 & 2.57 & 1.534 \\
\hline $28-2(8-10)$ & 15.8 & 4.67 & & 1.540 \\
\hline \multicolumn{5}{|l|}{ Veins and Vesicles } \\
\hline Sample 504B-2-1 (50-55) & 16.0 & 4.67 & 2.61 & 1.540 \\
\hline 4-1 (94-98) & 15.8 & 4.62 & 2.54 & 1.537 \\
\hline $5-3(2-6)$ & 15.2 & 4.58 & & 1.532 \\
\hline $7-2(14-20)$ & & 4.62 & 2.53 & 1.536 \\
\hline $13-3(79-83)$ & 15.2 & 4.59 & 2.55 & 1.534 \\
\hline $15-1(10-15)$ & 15.5 & 4.60 & 2.54 & 1.536 \\
\hline $15-5(95-100)$ & 15.1 & 4.61 & 2.53 & 1.536 \\
\hline $22-1(18-20)$ & 15.4 & 4.59 & & 1.536 \\
\hline $28-3(120-125)$ & 15.4 & 4.62 & & 1.536 \\
\hline \multicolumn{5}{|l|}{ Breccia Matrix } \\
\hline Sample 504B-10-1 (13-17) & 12.6 & 4.56 & 2.52 & 1.532 \\
\hline $10-3(80-85)$ & 14.8 & 4.57 & 2.55 & 1.536 \\
\hline $19-2(23-25)$ & 15.6 & 4.59 & 2.53 & 1.531 \\
\hline $21-1(11-15)$ & 15.5 & 4.57 & 2.53 & 1.531 \\
\hline $27-1(140-145)$ & 14.7 & 4.60 & 2.53 & 1.534 \\
\hline $28-2(90-95)$ & & 4.61 & 2.56 & 1.536 \\
\hline $29-1(11-14)$ & 15.2 & 4.58 & 2.51 & 1.534 \\
\hline
\end{tabular}

Table 4. Chemical composition of clay minerals in olivines.

\begin{tabular}{|c|c|c|c|c|c|c|c|c|c|c|c|c|c|c|c|c|c|c|c|c|c|}
\hline $\begin{array}{c}\text { Sample } \\
\text { (interval in } \mathrm{cm} \text { ) }\end{array}$ & $\mathrm{SiO}_{2}$ & $\mathrm{TiO}_{2}$ & $\mathrm{Al}_{2} \mathrm{O}_{3}$ & $\mathrm{FeO}$ & $\mathrm{MnO}$ & $\mathrm{MgO}$ & $\mathrm{CaO}$ & $\mathrm{Na}_{2} \mathrm{O}$ & $\mathrm{K}_{2} \mathrm{O}$ & Total & $\mathrm{Si}$ & $\mathrm{Ti}$ & Al & $\mathrm{Fe}$ & Mn & $\mathrm{Mg}$ & $\mathrm{Ca}$ & $\mathrm{Na}$ & K & $\Sigma^{a}$ & $\begin{array}{l}\text { Clay } \\
\text { Type }^{\mathrm{b}}\end{array}$ \\
\hline $504 \mathrm{~B}-4-5(87-89)$ & 51.85 & 0.05 & 2.56 & 8.56 & 0.12 & 22.97 & 0.72 & 0.09 & 0.19 & 87.11 & 7.556 & 0.005 & 0.439 & 1.040 & 0.015 & 5.021 & 0.112 & 0.025 & 0.035 & 6.076 & $\mathbf{Y}$ \\
\hline \multirow{3}{*}{$\begin{array}{r}5-1(142-147) \\
5.48\end{array}$} & 53.37 & 0.00 & 2.47 & 7.11 & 0.04 & 24.40 & 0.71 & 0.07 & 0.07 & 88.24 & 7.598 & 0.000 & 0.414 & 0.844 & 0.005 & 5.211 & 0.108 & 0.019 & 0.013 & 6.072 & $\mathbf{Y}$ \\
\hline & 51.89 & 0.05 & 2.61 & 9.36 & 0.16 & 22.38 & 0.83 & 0.08 & 0.08 & 87.44 & 7.561 & 0.005 & 0.447 & 1.137 & 0.020 & 4.892 & 0.130 & 0.023 & 0.015 & 6.062 & $\mathbf{Y}$ \\
\hline & 45.61 & 0.00 & 2.53 & 22.11 & 0.10 & 19.74 & 0.84 & 0.05 & 0.11 & 91.10 & 6.929 & 0.000 & 0.452 & 2.799 & 0.013 & 4.498 & 0.137 & 0.015 & 0.021 & 6.691 & R \\
\hline \multirow[t]{3}{*}{$6-2(90-95)$} & 49.67 & 0.03 & 3.62 & 8.77 & 0.05 & 21.56 & 0.60 & 0.10 & 0.10 & 84.40 & 7.471 & 0.003 & 0.641 & 1.099 & 0.006 & 4.864 & 0.097 & 0.029 & 0.019 & 6.084 & $\mathbf{Y}$ \\
\hline & 25.00 & 0.00 & 0.92 & 53.43 & 0.16 & 11.14 & 0.43 & 0.06 & 0.06 & 91.99 & 4.844 & 0.000 & 0.210 & 8.627 & 0.026 & 3.237 & 0.089 & 0.022 & 0.015 & 8.944 & $\mathbf{R}$ \\
\hline & 45.24 & 0.06 & 1.97 & 23.64 & 0.23 & 19.59 & 0.68 & 0.07 & 0.19 & 91.67 & 6.900 & 0.007 & 0.353 & 3.005 & 0.030 & 4.482 & 0.111 & 0.021 & 0.037 & 6.777 & $\mathbf{R}$ \\
\hline \multirow[t]{2}{*}{$7-1(93-97)$} & 47.13 & 0.00 & 5.02 & 9.92 & 0.22 & 21.20 & 1.05 & 0.47 & 0.12 & 85.13 & 7.149 & 0.000 & 0.896 & 1.254 & 0.028 & 4.824 & 0.171 & 0.138 & 0.023 & 6.123 & $\hat{Y}$ \\
\hline & 51.76 & 0.00 & 6.20 & 10.63 & 0.21 & 23.02 & 1.24 & 0.30 & 0.21 & 93.57 & 7.103 & 0.000 & 1.010 & 1.227 & 0.025 & 4.783 & 0.184 & 0.080 & 0.037 & 6.148 & $\mathbf{Y}$ \\
\hline $7-2(14-20)$ & 46.53 & 0.06 & 4.94 & 9.58 & 0.22 & 20.14 & 0.19 & 0.03 & 0.00 & 81.69 & 7.287 & 0.007 & 0.910 & 1.250 & 0.029 & 4.731 & 0.032 & 0.009 & 0.000 & 6.214 & $\dot{Y}$ \\
\hline \multirow[t]{3}{*}{$8-2(45-52)$} & 42.50 & 0.00 & 3.86 & 8.35 & 0.00 & 21.48 & 0.33 & 0.00 & 0.08 & 76.60 & 7.269 & 0.000 & 0.730 & 1.119 & 0.000 & 5.182 & 0.057 & 0.000 & 0.016 & 6.302 & $\dot{Y}$ \\
\hline & 41.12 & 0.02 & 2.71 & 23.06 & 0.04 & 14.92 & 0.84 & 0.06 & 0.59 & 83.36 & 6.958 & 0.003 & 0.539 & 3.252 & 0.006 & 3.787 & 0.152 & 0.020 & 0.127 & 6.545 & $\mathbf{R}$ \\
\hline & 52.10 & 0.00 & 1.03 & 24.95 & 0.11 & 5.98 & 0.47 & 0.04 & 6.94 & 91.52 & 8.138 & 0.000 & 0.189 & 3.248 & 0.015 & 1.401 & 0.079 & 0.012 & 1.384 & 4.853 & G \\
\hline $8-2(134-135)$ & 42.91 & 0.71 & 6.54 & 12.94 & 0.05 & 18.65 & 1.51 & 0.66 & 0.27 & 84.54 & 6.760 & 0.084 & 1.212 & 1.699 & 0.007 & 4.407 & 0.255 & 0.201 & 0.054 & 6.169 & $\mathrm{Y}$ \\
\hline \multirow{2}{*}{$9-1(38-42)$} & 55.30 & 0.01 & 1.61 & 4.74 & 0.09 & 26.61 & 0.69 & 0.03 & 0.11 & 89.19 & 7.689 & 0.001 & 0.263 & 0.549 & 0.011 & 5.550 & 0.103 & 0.008 & 0.020 & 6.060 & $\mathrm{Y}$ \\
\hline & 26.04 & 0.00 & 1.80 & 46.05 & 0.18 & 11.53 & 0.51 & 0.01 & 0.03 & 86.16 & 5.131 & 0.000 & 0.417 & 7.561 & 0.030 & 3.408 & 0.108 & 0.004 & 0.008 & 8.547 & $\mathbf{R}$ \\
\hline \multirow[t]{2}{*}{$9-1(120-123)$} & 49.98 & 0.00 & 5.43 & 9.43 & 0.04 & 21.35 & 1.38 & 0.11 & 0.13 & 87.85 & 7.271 & 0.000 & 0.931 & 1.145 & 0.005 & 4.668 & 0.216 & 0.031 & 0.024 & 6.020 & $\hat{\mathrm{Y}}$ \\
\hline & 52.43 & 0.04 & 2.72 & 24.86 & 0.00 & 5.38 & 0.72 & 0.10 & 5.95 & 92.20 & 8.056 & 0.005 & 0.492 & 3.183 & 0.000 & 1.240 & 0.119 & 0.030 & 1.167 & 4.915 & G \\
\hline \multirow[t]{3}{*}{$13-4(6-10)$} & 48.99 & 0.00 & 2.12 & 8.57 & 0.00 & 21.50 & 0.44 & 0.35 & 0.45 & 82.42 & 7.579 & 0.000 & 0.386 & 1.105 & 0.000 & 4.989 & 0.073 & 0.105 & 0.089 & 6.059 & $\mathrm{Y}$ \\
\hline & 41.02 & 0.07 & 2.44 & 30.75 & 0.02 & 11.35 & 0.93 & 0.11 & 1.50 & 88.19 & 6.880 & 0.009 & 0.481 & 4.298 & 0.003 & 2.855 & 0.167 & 0.036 & 0.321 & 6.526 & $\mathbf{R}$ \\
\hline & 52.88 & 0.06 & 0.75 & 26.15 & 0.02 & 5.23 & 0.43 & 0.02 & 6.35 & 91.89 & 8.230 & 0.007 & 0.137 & 3.391 & 0.003 & 1.221 & 0.072 & 0.006 & 1.262 & 4.752 & G \\
\hline $18-2(101-105)$ & 56.08 & 0.09 & 2.04 & 4.68 & 0.14 & 26.46 & 0.49 & 0.09 & 0.11 & 90.19 & 7.697 & 0.009 & 0.329 & 0.535 & 0.016 & 5.448 & 0.072 & 0.024 & 0.019 & 6.034 & $\mathbf{Y}$ \\
\hline $20-1(58-61)$ & 52.49 & 0.00 & 2.61 & 7.53 & 0.14 & 25.11 & 0.81 & 0.05 & 0.18 & 88.92 & 7.466 & 0.000 & 0.437 & 0.893 & 0.017 & 5.357 & 0.123 & 0.014 & 0.033 & 6.170 & $\dot{Y}$ \\
\hline \multirow[t]{3}{*}{$21-2(55-59)$} & 56.63 & 0.01 & 0.72 & 7.73 & 0.09 & 25.11 & 0.48 & 0.07 & 0.12 & 90.96 & 7.817 & 0.001 & 0.117 & 0.889 & 0.010 & 5.199 & 0.071 & 0.019 & 0.021 & 6.033 & $\mathbf{Y}$ \\
\hline & 42.55 & 0.11 & 2.41 & 23.80 & 0.12 & 19.12 & 1.01 & 0.08 & 0.17 & 89.38 & 6.715 & 0.013 & 0.447 & 3.130 & 0.016 & 4.526 & 0.171 & 0.024 & 0.034 & 6.847 & $\mathrm{R}$ \\
\hline & 11.13 & 0.00 & 0.36 & 64.00 & 0.13 & 4.08 & 0.46 & 0.03 & 0.06 & 80.25 & 2.949 & 0.000 & 0.112 & 14.13 & 0.029 & 1.622 & 0.131 & 0.015 & 0.020 & 10.85 & $\hat{\mathbf{R}}$ \\
\hline $24-2(69-73)$ & 53.53 & 0.04 & 2.27 & $\begin{array}{r}0.00 \\
8.40\end{array}$ & 0.20 & 24.98 & 0.74 & 0.12 & 0.08 & 90.36 & 7.514 & 0.004 & 0.375 & 0.983 & 0.024 & 5.260 & 0.111 & 0.033 & 0.014 & 6.160 & $\hat{\mathrm{Y}}$ \\
\hline \multirow[t]{3}{*}{$28-3(120-125)$} & 45.87 & 0.00 & 5.40 & 10.92 & 0.04 & 20.32 & 1.17 & 0.05 & 0.09 & 83.86 & 7.094 & 0.000 & 0.983 & 1.407 & 0.005 & 4.714 & 0.194 & 0.015 & 0.018 & 6.203 & $\hat{\mathrm{Y}}$ \\
\hline & 49.57 & 0.10 & 3.11 & 20.02 & 0.00 & 11.36 & 0.96 & 0.18 & 3.71 & 89.03 & 7.676 & 0.012 & 0.567 & 2.583 & 0.000 & 2.639 & 0.159 & 0.054 & 0.733 & 5.477 & G \\
\hline & 53.32 & 0.06 & 2.60 & 24.85 & 0.08 & 6.42 & 0.72 & 0.09 & 6.33 & 94.77 & 8.000 & 0.007 & 0.459 & 3.107 & 0.010 & 1.445 & 0.116 & 0.026 & 1.212 & 5.021 & G \\
\hline \multirow[t]{2}{*}{$28-5(14-17)$} & 54.14 & 0.06 & 1.79 & 14.26 & 0.04 & 20.71 & 0.94 & 0.06 & 0.20 & 92.20 & 7.650 & 0.006 & 0.298 & 1.679 & 0.005 & 4.389 & 0.142 & 0.016 & 0.036 & 6.027 & $\mathrm{Y}$ \\
\hline & 51.46 & 0.05 & 1.43 & 14.70 & 0.08 & 18.26 & 1.22 & 0.05 & 0.08 & 87.33 & 7.721 & 0.006 & 0.252 & 1.838 & 0.010 & 4.109 & 0.196 & 0.015 & 0.015 & 5.936 & $\mathrm{Y}$ \\
\hline
\end{tabular}

Note: Number of cations is based on 22 oxygens.

a Sum of octahedral cations.

b Y, yellow; R, red; G, green. 
Table 5. Chemical composition of clay minerals in veins and vesicles.

\begin{tabular}{|c|c|c|c|c|c|c|c|c|c|c|c|c|c|c|c|c|c|c|c|c|c|}
\hline $\begin{array}{c}\text { Sample } \\
\text { (interval in } \mathrm{cm} \text { ) }\end{array}$ & $\mathrm{SiO}_{2}$ & $\mathrm{TiO}_{2}$ & $\mathrm{Al}_{2} \mathrm{O}_{3}$ & $\mathrm{FeO}$ & $\operatorname{lnO}$ & $\mathrm{MgO}$ & $\mathrm{CaO}$ & $\mathrm{Na}_{2} \mathrm{O}$ & $\mathrm{K}_{2} \mathrm{O}$ & rotal & $\mathrm{Si}$ & $\mathrm{Ti}$ & $\mathrm{Al}$ & $\mathrm{Fe}$ & Mn & Mg & $\mathrm{Ca}$ & $\mathrm{Na}$ & K & $\Sigma^{\mathrm{a}}$ & $\underset{\text { Type }^{\text {Clay }}}{\text { Cla }}$ \\
\hline \multirow[t]{2}{*}{$504 \mathrm{~B}-4-4(32-35)$} & 47.00 & 0.04 & 5.39 & 9.35 & 0.03 & 21.59 & 0.57 & 0.17 & 0.05 & 84.19 & 7.152 & 0.005 & 0.965 & 1.186 & 0.004 & 4.928 & 0.093 & 0.050 & 0.010 & 5.240 & $x$ \\
\hline & 49.49 & 0.04 & 4.52 & 26.87 & 0.00 & 5.56 & 0.99 & 0.11 & 5.36 & 92.94 & 7.649 & 0.005 & 0.822 & 3.461 & 0.000 & 1.289 & 0.164 & 0.033 & 1.058 & 5.226 & G \\
\hline $5-1(142-147)$ & 53.08 & 0.09 & 3.11 & 8.97 & 0.06 & 23.19 & 0.89 & 0.10 & 0.15 & 89.60 & 7.522 & 0.010 & 0.519 & 1.059 & 0.007 & 4.930 & .135 & 0.027 & 0.027 & 6.047 & $\mathbf{Y}$ \\
\hline \multirow[t]{3}{*}{$6-2(90-95)$} & 51.46 & 0.07 & 3.19 & 9.97 & 0.13 & 21.58 & 0.87 & 0.16 & 0.15 & 87.58 & 7.516 & 0.008 & 0.548 & 1.213 & 0.016 & 4.728 & 0.136 & 0.045 & 0.028 & 6.029 & $\mathrm{y}$ \\
\hline & 40.51 & 0.23 & 3.27 & 32.76 & 0.09 & 11.03 & 1.38 & 0.16 & 1.05 & 90.50 & 6.683 & 0.028 & 0.635 & 4.504 & 0.013 & 2.729 & 0.244 & 0.051 & 0.221 & .592 & $\mathbf{R}$ \\
\hline & 48.50 & 0.05 & 3.18 & 27.32 & 0.10 & 9.05 & 1.30 & 0.23 & 2.10 & 91.83 & 7.510 & 0.006 & 0.579 & 3.526 & 0.013 & 2.102 & 0.216 & 0.069 & 0.415 & 5.736 & G \\
\hline $7-1$ (93-97) & 50.28 & 0.18 & 7.99 & 14.19 & 0.01 & 18.86 & 2.06 & 0.15 & 0.26 & 93.95 & 7.020 & 0.019 & 1.312 & 1.651 & 0.001 & 3.950 & 0.308 & 0.041 & 0.046 & 5.953 & $\mathbf{Y}$ \\
\hline \multirow[t]{3}{*}{$8-2(45-52)$} & 54.04 & 0.03 & 3.1 & 8.55 & 0.03 & 22.94 & 0.75 & 0.11 & 0.13 & 89.73 & 7.609 & 0.003 & 0.522 & 1.003 & 0.004 & 4.845 & 0.113 & 0.030 & 0.023 & 5.986 & $\mathbf{Y}$ \\
\hline & 39.22 & 0.01 & 2.78 & 27.24 & 0.09 & 15.49 & 0.68 & 0.17 & 0.24 & 85.92 & 6.616 & 0.001 & 0.552 & 3.829 & 0.013 & 3.919 & 0.123 & 0.056 & 0.052 & 6.930 & $\mathbf{R}$ \\
\hline & 51.96 & 0.02 & 1.88 & 25.26 & 0.01 & 5.65 & 0.89 & 0.10 & 5.45 & 91.22 & 8.088 & 0.002 & 0.344 & 3.277 & 0.001 & 1.319 & 0.148 & 0.030 & 1.083 & 4.941 & G \\
\hline \multirow[t]{4}{*}{$8-2(134-135)$} & 49.49 & 0.00 & 3.80 & 10.61 & 0.00 & 20.53 & 0.95 & 0.23 & 0.30 & 85.91 & 7.419 & 0.000 & 0.670 & 1.325 & 0.000 & 4.616 & 0.153 & 0.067 & 0.057 & 6.030 & Y \\
\hline & 50.86 & 0.01 & 3.09 & 8.85 & 0.05 & 23.21 & 0.76 & 0.29 & 0.15 & 87.27 & 7.429 & 0.001 & 0.531 & 1.077 & 0.006 & 5.085 & 0.119 & 0.082 & 0.028 & 6.129 & $\mathbf{Y}$ \\
\hline & 43.89 & 0.03 & 3.28 & 22.97 & 0.08 & 17.02 & 0.98 & 0.14 & 0.73 & 89.12 & 6.897 & 0.004 & 0.606 & 3.008 & 0.011 & 4.012 & 0.165 & 0.043 & 0.146 & 5.538 & $\mathbf{R}$ \\
\hline & 36.28 & 0.07 & 2.79 & 31.48 & 0.03 & 14.68 & 0.96 & 0.07 & 0.37 & 86.73 & 6.275 & 0.009 & 0.568 & 4.537 & 0.004 & 3.308 & 0.178 & 0.013 & 0.082 & 5.701 & $\mathbf{R}$ \\
\hline \multirow[t]{4}{*}{$9-1(38-42)$} & 51.08 & 0.02 & 4.22 & 11.48 & 0.21 & 20.79 & 1.16 & 0.08 & 0.08 & 89.12 & 7.396 & 0.002 & 0.719 & 1.385 & 0.026 & 4.515 & 0.180 & 0.022 & 0.015 & 6.043 & 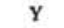 \\
\hline & 46.82 & 0.07 & 5.01 & 12.04 & 0.10 & 16.98 & 0.56 & 0.23 & 0.94 & 82.75 & 7.379 & 0.008 & 0.929 & 1.581 & 0.013 & 4.014 & 0.095 & 0.070 & 0.189 & .924 & $\mathbf{Y}$ \\
\hline & 41.11 & 0.46 & 4.5 & 22.20 & 0.17 & 16.20 & 0.97 & 0.24 & 0.41 & 86.30 & 6.681 & 0.056 & 0.866 & 3.006 & 0.023 & 3.949 & 0.169 & 0.075 & 85 & 6.5 & $\mathbf{R}$ \\
\hline & 50.07 & 0.07 & 4.17 & 25.60 & 0.1 & 6.38 & 1.20 & 0.15 & 4.30 & 91.43 & 7.714 & 0.008 & 0.756 & 3.287 & 0.017 & 1.474 & 0.198 & & 46 & 6 & G \\
\hline \multirow[t]{2}{*}{$9-1(120-123)$} & 50.45 & 0.00 & 5. & 9.59 & 0.00 & 21.19 & 1.66 & 0.13 & 0.20 & 88.62 & 7.291 & 0.000 & 0.918 & 1.155 & 0.000 & 4.593 & 0.257 & 0.036 & 0.037 & 5.957 & $\mathbf{Y}$ \\
\hline & 51.30 & 0.06 & 3. & 25.76 & 0.07 & 4.23 & 1.25 & 0.08 & 4.55 & 90.97 & 7.984 & 0.007 & 0.672 & 3.341 & 0.009 & 0.987 & 0.208 & & 0.904 & 8.000 & G \\
\hline \multirow[t]{2}{*}{$13-4(6-10)$} & 51.93 & 0.08 & 3.55 & 9.26 & 0.08 & 22.10 & 0.69 & 0.04 & 0.0 & 80 & 7.516 & 0.009 & 0.604 & 1.117 & & 4.7 & $n$ & 0. & 13 & 4 & $\mathbf{Y}$ \\
\hline & 50.40 & 0.10 & 1.43 & 27.96 & 0.0 & 6.29 & 0.69 & 0.0 & 4.1 & 91.15 & 7,936 & 0.012 & 0.265 & 3.669 & 0.012 & 1.4 & 0.116 & & 26 & 0 & J \\
\hline \multirow[t]{4}{*}{$17-1(145-150)$} & 47.45 & 0.01 & 5.63 & 8.57 & 0.08 & 22.03 & 0.52 & 0.0 & 0.0 & 84.45 & 7.161 & 0.001 & 1.000 & 1.078 & 0.010 & 4.987 & 0.084 & 26 & 0 & 7 & $\mathbf{Y}$ \\
\hline & 53.06 & 0.07 & 5.6 & 14.92 & 0.0 & 15.81 & 1.4 & 0.0 & 1.2 & 92.28 & 7.543 & 0.007 & 0.947 & 1.767 & 0.002 & 3.3 & 0.216 & 0.0 & 27 & 7 & $\mathbf{Y}$ \\
\hline & 33.13 & 0.04 & 2.43 & 44.84 & 0.13 & 3.48 & 0.7 & 0.0 & 2.6 & 84.39 & 6.297 & 0.006 & 0.5 & 7.1 & 0. & 0. & 0.1 & 0. & 31 & 1 & $\mathbf{R}$ \\
\hline & 53.19 & 0.03 & 2.5 & 22.61 & 0.06 & 8.02 & 0.84 & 0.0 & 4.57 & 91.96 & 8.029 & 0.003 & 0.453 & 2.844 & 0.008 & 1.816 & 0.136 & 0.026 & .881 & 5.121 & G \\
\hline \multirow[t]{4}{*}{$18-2(101-105)$} & 53.12 & 0.08 & $4 .($ & 7.89 & 0.1 & 24.19 & 0.9 & 0.1 & 0.12 & 90.61 & 7.413 & 0.008 & 0.665 & 0.918 & & & & & 1 & 11 & $\mathbf{y}$ \\
\hline & 42.93 & 0.06 & 4.6 & 22.74 & 0.13 & 18.84 & 1.44 & 0.1 & 0.1 & 3 & 6.597 & 0.007 & 0.8 & & 7 & 4. & 0.237 & 0. & 0.035 & 6.709 & $\mathbf{R}$ \\
\hline & 39.72 & 0.0 & & .34 & 0.1 & 12.04 & 0.94 & 0.2 & 1.2 & 6 & 6.676 & 0.003 & 0.571 & 4.3 & & & & & & & R \\
\hline & 46.60 & 0.05 & 3.9 & 22.88 & 0.0 & 10.89 & 1.00 & 0.1 & 2.7 & & 7.35 & 0.0 & 0.7 & & 3 & & 0.170 & 0.052 & 0.547 & 5.761 & G \\
\hline \multirow[t]{6}{*}{$19-1(119-122)$} & 45.15 & 0.00 & 4.4 & 9.36 & 0.1 & 20.51 & 0.24 & 0.12 & 0.0 & & 7.236 & 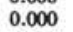 & 0.8 & 1.150 & 0 & & 0.041 & & 8 & & $\mathrm{y}$ \\
\hline & 50.16 & 0 & & 5 & 08 & 24.13 & 0.2 & 01 & & & 7.507 & & & & & & 0.0 & & 4 & 6.1 & $\mathbf{Y}$ \\
\hline & 49.95 & 0.00 & 4.38 & 17.89 & 0.0 & 12.72 & 0.94 & 0.11 & 0.6 & 86 & 7.672 & 0.000 & 0.791 & 2.290 & 0.012 & 2.930 & 0.155 & 0.033 & 0.133 & 5.695 & $\mathbf{Y}$ \\
\hline & 53.20 & 000 & 3.2 & 21.22 & 0.0 & 10.45 & 0.69 & 0.26 & 3. & & & & & & & & 0.109 & & & & G \\
\hline & 52.26 & 0.01 & 2.69 & 20.21 & 0.0 & 8.26 & 0. & 0.0 & 6. & & 8.010 & 0.001 & 0.4 & 2.581 & 0.0 & 1.899 & 0.128 & 0.027 & 1.241 & 4.973 & G \\
\hline & 35.87 & 0.00 & & 32.67 & 0.1 & 16.11 & 0. & 0. & 0. & 8 & 6.141 & & & 4.461 & & & & & & & $\mathbf{R}$ \\
\hline \multirow[t]{2}{*}{$20-1(58-61)$} & 51.63 & 0.0 & 3. & 9.61 & 0. & 22.80 & 1. & & & & 7.415 & 0.001 & 0.596 & 1.150 & 0.016 & 4.912 & 0.174 & 0.022 & .020 & 6.090 & $\mathrm{Y}$ \\
\hline & 34.61 & 0.0 & 2. & 35.64 & 0.1 & 15 & 0.8 & 0.0 & 0.0 & 89.03 & 5.988 & 0.003 & 0.5 & 5.138 & 0.018 & & 0.159 & & & 7.585 & $\mathbf{R}$ \\
\hline \multirow[t]{3}{*}{$21-1(70-75)$} & 50.33 & 0.01 & & 8.66 & & 21.96 & & & & & 7.318 & 0.0 & 0.818 & 1.051 & 0.000 & 4.799 & 0.250 & 0.039 & 0.030 & 5.987 & $\mathbf{Y}$ \\
\hline & 49.06 & 0.02 & 8. & 17.09 & 0. & 16.07 & 2. & 0.1 & 0.2 & 3 & 6.985 & 0.002 & 1.412 & 2.028 & 0.0 & & & 0.039 & & 5.859 & $\mathbf{Y}$ \\
\hline & 52. & 0. & & 22.37 & & & 1.2 & & & & & & & & & & 0.198 & 0.026 & 0.914 & 5.047 & G \\
\hline \multirow[t]{2}{*}{$21-1(132-135)$} & 51.56 & 0.01 & 3.1 & 9.76 & 0.11 & 22.23 & 0.8 & 0.1 & 0.1 & & 7.478 & 0.001 & 0.548 & 1.187 & 0.014 & 4.8 & 0.131 & 0.028 & 0.020 & 6.095 & $\mathbf{Y}$ \\
\hline & 31.31 & & & 40.39 & 0.12 & 13.38 & 0.7 & 0.0 & 0. & & & & & & & & 0.136 & 0.021 & 0.009 & 7.920 & $\mathbf{R}$ \\
\hline $25-1(34-38)$ & 50.84 & 0.10 & 3.1 & 26.01 & 0.1 & 4.74 & 0.8 & 0.1 & 4. & & 7.959 & 0.012 & 0.576 & 3.393 & 0.021 & 1.113 & 0.141 & 0.056 & 0.997 & 5.074 & G \\
\hline \multirow[t]{3}{*}{$28-3(120-125)$} & 44.26 & 0.00 & 5.58 & 11.17 & 0.13 & 18.86 & 1.04 & 0.2 & 0.1 & 81.37 & 7.083 & 0.0 & 1.051 & 1.490 & 0.018 & 4.528 & 0.178 & 0.062 & 0.027 & 6.170 & $\mathbf{Y}$ \\
\hline & 46.37 & 0.13 & 3.4 & 29. & 0.0 & 4. & 0. & 0. & 5.2 & & 7.582 & & 0.654 & 4.043 & 0.000 & 1.037 & 0.172 & 0.047 & 1.096 & 5.332 & G \\
\hline & 51.28 & 0.01 & 3.35 & 25.84 & 0.15 & 5.15 & 0.86 & 0.14 & 5.95 & 92.73 & 7.904 & 0.001 & 0.607 & 3.319 & 0.020 & 1.191 & 0.142 & 0.042 & 1.171 & 5.042 & G \\
\hline
\end{tabular}

Note: Number of cations is based on 22 oxygens.

a Sum of octahedral cation.

Y, yellow; G, green; R, red.

Table 6. Microprobe analysis of zeolites.

\begin{tabular}{lrrrrrrr}
\hline \multicolumn{7}{c}{$\begin{array}{c}\text { Sample } \\
\text { (interval in cm })\end{array}$} \\
\cline { 2 - 8 } & $\begin{array}{c}501-11-1 \\
(0-3)\end{array}$ & $\begin{array}{c}501-19-1 \\
(73-77)\end{array}$ & $\begin{array}{c}504 \mathrm{~B}-7-1 \\
(93-97)\end{array}$ & $\begin{array}{c}504 \mathrm{~B}-7-2 \\
(14-20)\end{array}$ & $\begin{array}{c}504 \mathrm{~B}-10-3 \\
(88-92)\end{array}$ & $\begin{array}{c}504 \mathrm{~B}-21-1 \\
(11-15)\end{array}$ & $\begin{array}{c}504 \mathrm{~B}-29-1 \\
(11-14)\end{array}$ \\
\hline $\mathrm{SiO}_{2}$ & 61.03 & 61.25 & 62.81 & 61.91 & 58.97 & 60.39 & 59.69 \\
$\mathrm{TiO}_{2}$ & 0.06 & 0.00 & 0.00 & 0.01 & 0.00 & 0.00 & 0.03 \\
$\mathrm{Al}_{2} \mathrm{O}_{3}$ & 19.84 & 22.41 & 20.21 & 20.63 & 21.42 & 21.85 & 21.93 \\
$\mathrm{FeO}$ & 0.09 & 0.01 & 0.16 & 0.20 & 0.03 & 0.14 & 0.09 \\
$\mathrm{MnO}$ & 0.00 & 0.02 & 0.05 & 0.00 & 0.03 & 0.06 & 0.00 \\
$\mathrm{MgO}$ & 0.01 & 0.00 & 0.02 & 0.08 & 0.05 & 0.03 & 0.02 \\
$\mathrm{CaO}$ & 0.36 & 1.55 & 0.79 & 0.96 & 0.93 & 2.01 & 3.18 \\
$\mathrm{Na} 2 \mathrm{O}$ & 4.56 & 3.22 & 4.78 & 4.46 & 4.03 & 5.11 & 3.26 \\
$\mathrm{~K}_{2} \mathrm{O}$ & 6.69 & 4.99 & 5.03 & 4.72 & 4.77 & 3.95 & 3.61 \\
$\mathrm{Total}$ & 92.64 & 93.45 & 93.85 & 92.97 & 90.23 & 93.54 & 91.81 \\
$\mathrm{Si}$ & 11.74 & 11.53 & 11.81 & 11.73 & 11.52 & 11.42 & 11.43 \\
$\mathrm{Ti}$ & 0.01 & 0.00 & 0.00 & 0.00 & 0.00 & 0.00 & 0.00 \\
$\mathrm{Al}$ & 4.49 & 4.96 & 4.47 & 4.60 & 4.92 & 4.86 & 4.94 \\
$\mathrm{Fe}$ & 0.01 & 0.00 & 0.03 & 0.03 & 0.00 & 0.02 & 0.01 \\
$\mathrm{Mn}$ & 0.00 & 0.00 & 0.01 & 0.00 & 0.00 & 0.01 & 0.00 \\
$\mathrm{Mg}$ & 0.00 & 0.00 & 0.01 & 0.02 & 0.01 & 0.01 & 0.01 \\
$\mathrm{Ca}$ & 0.07 & 0.31 & 0.16 & 0.19 & 0.19 & 0.41 & 0.65 \\
$\mathrm{Na}$ & 1.70 & 1.17 & 1.74 & 1.64 & 1.52 & 1.87 & 1.21 \\
$\mathrm{~K}$ & 1.64 & 1.20 & 1.21 & 1.14 & 1.19 & 0.95 & 0.88 \\
$\mathrm{Si} / \mathrm{Al}$ & 2.61 & 2.32 & 2.64 & 2.55 & 2.34 & 2.35 & 2.31 \\
\hline $\mathrm{Na}$ & & & & & & & \\
\hline
\end{tabular}

Note: Structural formula is based on 32 oxygens. 
Table 7. Microprobe analysis of carbonates.

\begin{tabular}{|c|c|c|c|}
\hline & \multicolumn{3}{|c|}{$\begin{array}{l}\text { Sample } \\
\text { (interval in } \mathrm{cm} \text { ) }\end{array}$} \\
\hline & $\begin{array}{l}504 \mathrm{~B}-5-1 \\
(142-147)^{\mathrm{a}}\end{array}$ & $\begin{array}{l}504 \mathrm{~B}-21-2 \\
(55-59)^{\mathrm{b}}\end{array}$ & $\begin{array}{c}\text { 504B-28-5 } \\
(14-17)^{\mathrm{a}}\end{array}$ \\
\hline $\mathrm{SiO}_{2}$ & 0.00 & 0.14 & 0.01 \\
\hline $\mathrm{TiO}_{2}$ & 0.00 & 0.03 & 0.00 \\
\hline $\mathrm{Al}_{2} \mathrm{O}_{3}$ & 0.09 & 0.00 & 0.02 \\
\hline $\mathrm{FeO}$ & 0.08 & 0.12 & 0.04 \\
\hline $\mathrm{MnO}$ & 0.00 & 1.97 & 0.01 \\
\hline $\mathrm{MgO}$ & 0.00 & 0.63 & 0.04 \\
\hline $\mathrm{CaO}$ & 57.16 & 54.24 & 55.75 \\
\hline $\mathrm{Na}_{2} \mathrm{O}$ & 0.06 & 0.00 & 0.01 \\
\hline $\mathrm{K}_{2} \mathrm{O}$ & 0.01 & 0.00 & 0.01 \\
\hline Total & 57.40 & 57.16 & 55.89 \\
\hline
\end{tabular}

b Olivine.
Table 8. Microprobe analysis of mineral tentatively identified as anhydrite.

\begin{tabular}{lc}
\hline & $\begin{array}{c}\text { Sample } \\
504 \mathrm{~B}-18-2 \\
(101-105 \mathrm{~cm})\end{array}$ \\
\hline $\mathrm{SiO}_{2}$ & 0.04 \\
$\mathrm{TO}_{2}$ & 0.00 \\
$\mathrm{Al}_{2} \mathrm{O}_{3}$ & 0.00 \\
$\mathrm{FeO}$ & 0.14 \\
$\mathrm{MnO}$ & 0.07 \\
$\mathrm{MgO}$ & 0.04 \\
$\mathrm{CaO}$ & 37.89 \\
$\mathrm{Na} 2 \mathrm{O}$ & 0.02 \\
$\mathrm{~K}_{2} \mathrm{O}$ & 0.00 \\
Total & 38.20 \\
\hline
\end{tabular}

Table 9. Microprobe analysis of fresh glass and palagonite in Site 501 and 504 basalts.

\begin{tabular}{|c|c|c|c|c|c|}
\hline & $\begin{array}{l}\text { Fresh } \\
\text { Glass }\end{array}$ & \multicolumn{3}{|c|}{ Palagonite } & \\
\hline \multicolumn{6}{|c|}{ Sample $501-15-4,0-6 \mathrm{~cm}$} \\
\hline $\mathrm{SiO}_{2}$ & 51.33 & 40.50 & 44.40 & 42.74 & \\
\hline $\mathrm{TiO}_{2}$ & 0.82 & 0.97 & 0.47 & 0.41 & \\
\hline $\mathrm{Al}_{2} \mathrm{O}_{3}$ & 14.96 & 11.03 & 12.60 & 11.25 & \\
\hline $\mathrm{FeO}$ & 9.09 & 13.90 & 16.05 & 16.36 & \\
\hline $\mathrm{MnO}$ & 0.16 & 0.09 & 0.52 & 0.28 & \\
\hline $\mathrm{MgO}$ & 8.59 & 14.26 & 13.24 & 13.92 & \\
\hline $\mathrm{CaO}$ & 12.56 & 1.09 & 1.24 & 1.44 & \\
\hline $\mathrm{Na}_{2} \mathrm{O}$ & 2.22 & 0.33 & 0.09 & 0.23 & \\
\hline $\mathrm{K}_{2} \mathrm{O}$ & 0.00 & 0.48 & 0.86 & 0.72 & \\
\hline Total & 99.72 & 82.65 & 89.46 & 87.35 & \\
\hline \multicolumn{6}{|c|}{ Sample 504B-4-5, $87-89 \mathrm{~cm}$} \\
\hline $\mathrm{SiO}_{2}$ & 51.36 & 49.18 & 41.67 & 40.75 & 43.04 \\
\hline $\mathrm{TiO}_{2}^{2}$ & 0.94 & 1.27 & 0.52 & 0.02 & 0.02 \\
\hline $\mathrm{Al}_{2} \mathrm{O}_{3}$ & 14.83 & 14.59 & 15.09 & 13.82 & 15.30 \\
\hline $\mathrm{FeO}$ & 8.63 & 9.19 & 12.82 & 15.08 & 11.55 \\
\hline $\mathrm{MnO}$ & 0.11 & 0.04 & 0.38 & 0.26 & 0.24 \\
\hline $\mathrm{MgO}$ & 8.88 & 6.77 & 13.22 & 14.37 & 14.18 \\
\hline $\mathrm{CaO}$ & 12.35 & 3.49 & 1.98 & 1.50 & 1.85 \\
\hline $\mathrm{Na}_{2} \mathrm{O}$ & 2.05 & 0.28 & 0.12 & 0.14 & 0.12 \\
\hline $\mathrm{K}_{2} \mathrm{O}$ & 0.04 & 1.05 & 0.37 & 0.33 & 0.33 \\
\hline Total & 99.19 & 95.87 & 86.17 & 86.27 & 86.63 \\
\hline
\end{tabular}

Table 10. Bulk rock analysis.

\begin{tabular}{|c|c|c|c|c|c|c|c|c|c|c|c|c|c|c|c|}
\hline $\begin{array}{c}\text { Sample } \\
\text { (interval in } \mathrm{cm} \text { ) }\end{array}$ & $\mathrm{SiO}_{2}$ & $\mathrm{TiO}_{2}$ & $\mathrm{Al}_{2} \mathrm{O}_{3}$ & $\mathrm{Fe}_{2} \mathrm{O}_{3}$ & $\mathrm{FeO}$ & $\mathrm{MnO}$ & $\mathrm{MgO}$ & $\mathrm{CaO}$ & $\mathrm{Na}_{2} \mathrm{O}$ & $\mathrm{K}_{2} \mathrm{O}$ & $\mathrm{P}_{2} \mathrm{O}_{5}$ & $\mathrm{H}_{2} \mathrm{O}^{+}$ & $\mathrm{Sr}$ & $O x^{a}$ & $\begin{array}{l}\text { Zone } \\
\text { Type }^{b}\end{array}$ \\
\hline $504 \mathrm{~B}-3-1(16-19)$ & 50.03 & 1.01 & 14.71 & 4.49 & 5.78 & 0.18 & 8.03 & 12.29 & 2.26 & 0.27 & 0.08 & 0.86 & 79 & 0.411 & - \\
\hline $4-1(35-40)$ & 49.75 & 0.86 & 15.85 & 3.15 & 5.91 & 0.18 & 8.36 & 12.99 & 2.21 & 0.11 & 0.07 & 0.57 & 77 & 0.324 & - \\
\hline $5-1(106-109)$ & 49.53 & 0.89 & 16.11 & 3.64 & 5.33 & 0.18 & 7.76 & 13.08 & 2.35 & 0.07 & 0.07 & 0.98 & 82 & 0.381 & - \\
\hline $5-2(15-20)$ & 49.47 & 0.88 & 15.96 & 3.52 & 5.67 & 0.18 & 7.70 & 13.31 & 2.23 & 0.05 & 0.06 & 0.97 & 79 & 0.358 & - \\
\hline $6-2(108-112)$ & 49.46 & 1.00 & 14.99 & 4.47 & 5.29 & 0.18 & 8.45 & 12.32 & 2.53 & 0.25 & 0.08 & 0.99 & 83 & 0.432 & - \\
\hline $7-5(63-65)$ & 50.40 & 0.89 & 15.89 & 2.35 & 5.98 & 0.17 & 8.11 & 13.06 & 2.36 & 0.01 & 0.06 & 0.72 & 79 & 0.261 & - \\
\hline $8-1(1-2)$ & 50.03 & 0.89 & 16.01 & 3.47 & 5.53 & 0.16 & 7.73 & 13.04 & 2.26 & 0.11 & 0.06 & 0.70 & 81 & 0.361 & - \\
\hline \multirow[t]{3}{*}{$8-2(45-52)$} & 50.03 & 0.91 & 16.51 & 2.65 & 5.08 & 0.14 & 8.61 & 12.82 & 2.32 & 0.03 & 0.06 & 0.86 & 82 & 0.319 & LGY \\
\hline & 49.58 & 0.89 & 16.03 & 3.58 & 5.58 & 0.15 & 8.05 & 13.07 & 2.17 & 0.09 & 0.06 & 0.75 & 81 & 0.366 & OR \\
\hline & 49.71 & 0.85 & 15.93 & 3.95 & 5.47 & 0.14 & 7.52 & 13.08 & 2.27 & 0.23 & 0.06 & 0.79 & 79 & 0.394 & DGY \\
\hline $8-4(120-123)$ & 49.41 & 0.84 & 15.90 & 3.67 & 5.51 & 0.19 & 8.15 & 13.01 & 2.46 & 0.03 & 0.06 & 0.76 & 78 & 0.375 & - \\
\hline \multirow[t]{2}{*}{$9-1(38-42)$} & 49.71 & 0.89 & 16.54 & 2.91 & 5.02 & 0.18 & 7.95 & 13.06 & 2.48 & 0.03 & 0.06 & 1.17 & 94 & 0.343 & LGY : \\
\hline & 49.02 & 0.87 & 16.11 & 4.22 & 5.47 & 0.17 & 7.63 & 13.16 & 2.17 & 0.08 & 0.06 & 1.04 & 95 & 0.410 & OR \\
\hline $9-2(80-83)$ & 49.70 & 0.91 & 15.46 & 4.66 & 5.43 & 0.18 & 7.69 & 12.55 & 2.16 & 0.34 & 0.08 & 0.83 & 65 & 0.436 & - \\
\hline $10-2(12-14)$ & 50.26 & 0.94 & 15.32 & 3.98 & 5.25 & 0.17 & 8.09 & 12.60 & 2.28 & 0.27 & 0.07 & 0.76 & 91 & 0.406 & - \\
\hline $16-2(5-10)$ & 50.68 & 0.97 & 15.83 & 2.91 & 5.09 & 0.18 & 8.71 & 12.39 & 2.27 & 0.01 & 0.07 & 0.87 & 74 & 0.340 & - \\
\hline $17-2(86-90)$ & 49.31 & 0.88 & 15.93 & 3.57 & 5.81 & 0.19 & 8.24 & 12.85 & 2.13 & 0.18 & 0.07 & 0.83 & 96 & 0.356 & - \\
\hline $17-2(130-137)$ & 49.53 & 0.94 & 16.61 & 3.64 & 4.91 & 0.17 & 8.48 & 12.05 & 2.36 & 0.06 & 0.09 & 1.17 & 101 & 0.400 & - \\
\hline $18-1(110-115)$ & 48.99 & 1.29 & 16.80 & 4.44 & 4.67 & 0.18 & 6.71 & 12.72 & 2.44 & 0.15 & 0.20 & 1.41 & 175 & 0.461 & - \\
\hline $19-1(98-103)$ & 49.09 & 1.28 & 16.60 & 3.94 & 4.82 & 0.21 & 7.25 & 12.75 & 2.46 & 0.20 & 0.19 & 1.21 & 176 & 0.424 & - \\
\hline $19-1(119-122)$ & 49.16 & 1.30 & 16.25 & 4.56 & 4.71 & 0.19 & 6.97 & 13.41 & 2.59 & 0.34 & 0.20 & 1.30 & 184 & 0.466 & - \\
\hline $19-2(93-95)$ & 49.64 & 0.83 & 16.14 & 3.16 & 5.89 & 0.19 & 8.22 & 13.08 & 2.11 & 0.10 & 0.06 & 0.58 & 75 & 0.326 & - \\
\hline \multirow[t]{2}{*}{$20-1(58-61)$} & 49.11 & 0.95 & 15.53 & 4.80 & 4.70 & 0.19 & 8.11 & 12.89 & 2.55 & 0.05 & 0.07 & 1.05 & 101 & 0.479 & LGY \\
\hline & 49.08 & 1.08 & 15.19 & 5.20 & 4.68 & 0.17 & 8.11 & 12.57 & 2.51 & 0.16 & 0.08 & 1.18 & 101 & 0.500 & OR \\
\hline \multirow[t]{2}{*}{$21-1(132-135)$} & 49.17 & 0.96 & 16.09 & 4.64 & 4.65 & 0.18 & 7.82 & 12.83 & 2.48 & 0.05 & 0.07 & 1.07 & 99 & 0.473 & OR \\
\hline & 48.91 & 0.98 & 16.47 & 5.13 & 4.40 & 0.16 & 7.35 & 12.66 & 2.59 & 0.16 & 0.09 & 1.08 & 110 & 0.512 & DGY \\
\hline \multirow[t]{2}{*}{$21-2(55-59)$} & 48.64 & 0.70 & 19.40 & 2.72 & 5.09 & 0.17 & 7.21 & 13.31 & 2.03 & 0.02 & 0.05 & 0.67 & 69 & 0.325 & LGY \\
\hline & 49.33 & 0.72 & 16.88 & 3.63 & 5.31 & 0.17 & 7.28 & 13.72 & 2.03 & 0.03 & 0.04 & 0.87 & 69 & 0.381 & OR \\
\hline $21-3(145-150)$ & 49.26 & 0.95 & 15.68 & 3.98 & 5.42 & 0.21 & 7.96 & 12.99 & 2.35 & 0.06 & 0.07 & 1.07 & 103 & 0.398 & - \\
\hline $23-1(73-75)$ & 49.67 & 0.84 & 16.12 & 3.13 & 5.94 & 0.18 & 8.03 & 13.09 & 2.15 & 0.04 & 0.07 & 0.73 & 70 & 0.322 & - \\
\hline $25-1(34-38)$ & 49.59 & 0.93 & 14.57 & 5.32 & 5.36 & 0.17 & 7.86 & 12.37 & 2.32 & 0.46 & 0.06 & 0.99 & 86 & 0.472 & - \\
\hline $25-2(36-38)$ & 50.49 & 0.95 & 15.03 & 3.46 & 5.51 & 0.16 & 8.43 & 12.70 & 2.41 & 0.13 & 0.07 & 0.67 & 78 & 0.361 & - \\
\hline $27-1(105-110)$ & 50.33 & 0.96 & 14.74 & 4.02 & 5.64 & 0.18 & 8.14 & 12.72 & 2.23 & 0.34 & 0.07 & 0.63 & 75 & 0.391 & - \\
\hline $28-4(125-130)$ & 49.84 & 0.93 & 16.24 & 3.52 & 5.54 & 0.18 & 7.47 & 13.12 & 2.22 & 0.15 & 0.08 & 0.71 & 69 & 0.364 & - \\
\hline $28-5(14-17)$ & 49.84 & 0.86 & 15.64 & 2.88 & 6.26 & 0.16 & 8.22 & 13.28 & 2.14 & 0.02 & 0.06 & 0.64 & 75 & 0.293 & - \\
\hline $29-1(50-52)$ & 50.51 & 0.95 & 14.83 & 3.54 & 5.67 & 0.19 & 8.30 & 12.78 & 2.19 & 0.24 & 0.07 & 0.72 & 76 & 0.360 & - \\
\hline
\end{tabular}

$\mathrm{a}=\left(\mathrm{Fe}_{2} \mathrm{O}_{3} / 80\right) /\left(\mathrm{Fe}_{2} \mathrm{O}_{3} / 80+\mathrm{FeO} / 72\right)$.

b LGY, light gray; OR, orange; DGY, dark gray.

Table 11. Correlation matrix for major and trace elements.

\begin{tabular}{lccccccccccc}
\hline & $\mathrm{TiO}_{2}$ & $\mathrm{Al}_{2} \mathrm{O}_{3}$ & $\mathrm{Fe}_{2} \mathrm{O}_{3}$ & $\mathrm{FeO}$ & $\mathrm{MgO}$ & $\mathrm{CaO}$ & $\mathrm{Na}_{2} \mathrm{O}$ & $\mathrm{K}_{2} \mathrm{O}$ & $\mathrm{H}_{2} \mathrm{O}^{+}$ & $\mathrm{Sr}$ & $\mathrm{Ox}$ \\
\hline $\mathrm{SiO}_{2}$ & -0.01 & -0.32 & +0.09 & +0.41 & +0.45 & -0.12 & +0.09 & +0.05 & -0.61 & -0.63 & -0.39 \\
$\mathrm{TiO}_{2}$ & & +0.12 & +0.57 & -0.58 & +0.13 & -0.68 & +0.53 & +0.32 & +0.47 & +0.40 & +0.62 \\
$\mathrm{Al}_{2} \mathrm{O}_{3}$ & & & -0.43 & +0.05 & -0.23 & +0.41 & +0.13 & +0.07 & +0.18 & +0.16 & -0.27 \\
$\mathrm{Fe}_{2} \mathrm{O}_{3}$ & & & & -0.54 & -0.41 & -0.45 & +0.39 & +0.47 & +0.51 & +0.46 & +0.97 \\
$\mathrm{FeO}$ & & & & & -0.11 & +0.42 & -0.77 & +0.03 & -0.76 & -0.69 & -0.74 \\
$\mathrm{MgO}$ & & & & & & -0.38 & -0.05 & -0.19 & -0.19 & -0.13 & -0.38 \\
$\mathrm{CaO}$ & & & & & & & -0.31 & -0.49 & -0.32 & -0.20 & -0.48 \\
$\mathrm{Na}_{2} \mathrm{O}$ & & & & & & & & -0.12 & +0.63 & +0.60 & +0.29 \\
$\mathrm{~K}_{2} \mathrm{O}$ & & & & & & & & & -0.10 & -0.11 & +0.45 \\
$\mathrm{H}_{2} \mathrm{O}^{+}$ & & & & & & & & & & +0.76 & +0.63 \\
$\mathrm{Sr}$ & & & & & & & & & & +0.59 \\
\hline
\end{tabular}

